\title{
Analysing Supply Chain Resilience: Integrating the Constructs in a Concept Mapping Framework Via a Systematic Literature Review
}

\author{
Abubakar Ali \\ Technological University Dublin \\ Amr Mahfouz \\ Technological University Dublin, amr.mahfouz@tudublin.ie \\ Amr Arisha \\ Technological University Dublin, amr.arisha@tudublin.ie
}

Follow this and additional works at: https://arrow.tudublin.ie/buschgraart

Part of the Business Administration, Management, and Operations Commons

\section{Recommended Citation}

Ali, A., Mahfouz, A. \& Arisha, A. (2017). Analysing supply chain resilience:integrating the constructs in a concept mapping framework via a systematic literature review. Supply Change Management, vol.22(1). doi:10.1108/SCM-06-2016-0197

This Article is brought to you for free and open access by the Graduate Business School at ARROW@TU Dublin. It has been accepted for inclusion in Articles by an authorized administrator of ARROW@TU Dublin. For more information, please contact arrow.admin@tudublin.ie, aisling.coyne@tudublin.ie,gerard.connolly@tudublin.ie.

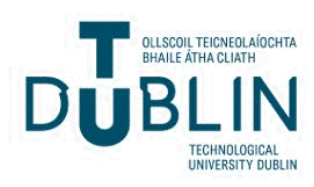




\title{
Analysing supply chain resilience: integrating the constructs in a concept mapping framework via a systematic literature review
}

\begin{abstract}
Purpose: The purpose of this paper is to analyse the concept of supply chain resilience (SCRES) using a concept mapping framework to seek conceptual clarity, with an emphasis on SCRES definitions, essential capabilities, elements and managerial practices.

Design/methodology/approach: A systematic literature review was conducted of 103 peerreviewed journal articles covering the period from 2000 to 2015, with the aim to identify supply chain resilience concept.

Findings: Through analysis and synthesis of the literature, the study revealed three major constructs used to define resilience in supply chain: SCRES phases, strategies, and capabilities. The study has addressed five core resilience capabilities: the ability to anticipate, to adapt, to respond, to recover, and to learn. The study has also identified 13 essential elements and several managerial practices that support firms to acquire the five capabilities. The studied capabilities are then linked with supply chain resilient phases and strategies in order to establish an integrated view of the concept.
\end{abstract}

Research limitations/implications: The explorative nature of this study and the role of the concept mapping framework, which does not empirically test the relationships in the model, are considered as limitations, to be addressed by the authors in future research.

Originality/value: The originality of this paper lies in the classification of different features of SCRES through a comprehensive concept mapping framework that establishes relationships and interactions between them. This study, therefore, lays a foundation for testing these connections in future empirical studies. The article brings together fragmented literature from multiple studies to create a solid body of knowledge that addresses the need for conceptual clarity in SCRES literature.

Keywords: Supply chain resilience, systematic literature review, concept mapping 


\section{Introduction}

Research on supply chain resilience (SCRES) has increased substantially over the years, with researchers and practitioners showing strong interest in it due to its potential impact on business continuity and competitiveness (Christopher and Peck, 2004; Sheffi, 2015). This interest represents a shift in businesses away from traditional risk management thinking, which is insufficient in addressing the increased vulnerabilities, uncertainties and unforeseen disruptions faced by complex global supply chains (Pettit et al., 2013; Fiksel et al., 2015). As supply chain networks enter an era of turbulence, new approaches and thinking are required in areas such as designing, building and managing supply chains, in order to insulate them from disturbances (Christopher and Holweg, 2011). Building resilience is deemed an essential strategic capability (Sheffi and Rice 2005; Seville et al., 2015) that enables the supply chain to anticipate, adapt, respond and recover promptly from unpredictable events (Rice and Caniato, 2003; Ponomarov and Holcomb, 2009; Blackhurst et al., 2011; Jüttner and Maklan, 2011). A resilient supply chain is perceived to absorb disturbances, restore its function, and 'bounce back' from adversity while maintaining a competitive advantage (Sheffi, 2007; Wieland and Wallenburg, 2013; Chopra and Sodhi, 2014). The concept of SCRES can therefore be promising when cultivated and implemented effectively in the field of supply chain management (SCM).

Current research on SCRES indicates that, to achieve resilience, it is vital for firms to build certain operational capabilities that must be aligned with supply chain partners to manage both expected and unexpected changes (Christopher and Peck, 2004; Sheffi and Rice, 2005; Ponomarov and Holcomb, 2009; Pettit et al., 2010). However, the published research on SCRES remains fragmented, with too much disparity in the definitions of the concept, inconsistent identification of its constructs, and a lack of clarity on the relationships between them. Further theoretical explanation is needed to improve the conceptual clarity. Indeed, many researchers have highlighted these limitations in recent years (Ponomarov and Holcomb, 2009; Bhamra et al., 2011; Blackhurst et al., 2011; Jüttner and Maklan, 2011; Melnyk et al., 2014). Despite the growing body of literature on SCRES, few attempts have been made to address these issues.

Recent studies have addressed certain aspects of the gaps outlined above through a systematic review of the literature. For example, Hohenstein et al. (2015) suggest an appropriate definition and essential elements of SCRES; Pereira et al. (2014) focus on enablers and 
barriers of SCRES elements, and Tukamuhabwa et al. (2015) propose a suitable theoretical lens to examine SCRES. Few studies, however, have sought to improve the conceptual clarity by consolidating the various SCRES constructs in an integrated and systematic way, in order to enhance overall perception of the concept.

In addressing these gaps, the aim of this study is to analyse SCRES concept to seek conceptual clarity, with an emphasis on SCRES definitions, essential elements and managerial practices, within a holistic model. A holistic model of SCRES is presented through a concept mapping framework guided by a systematic review of the literature. A concept map provides a useful framework to organise and represent knowledge on a topic (Novak and Cañas, 2008), and to identify key constructs so as to understand the theory, concepts and relationships between them (Rowley and Slack, 2004). This paper synthesises the accumulated findings, using integrative synthesis, and draws on a range of methodological approaches in the extant literature to address the review question: How can the concept of supply chain resilience be analysed to inform research and practice?

A key contribution of this framework is that it enables analysis of the potential of SCRES through the relationships of its constructs by evaluating and synthesising the current body of knowledge. Moreover, the framework lays the foundations for future research to explore the underlying theory and practice involved, with a view to creating resilient supply chains. The paper contributes to better understanding of SCRES, and has both theoretical and practical implications. It adds value to the body of SCRES knowledge and bridges the research gap by using concept mapping to understand the complex relationships and dynamic interplays between SCRES constructs. Also, it increases managerial awareness of the interlinks between the constructs in building SCRES capabilities, which leads to better practices in terms of creating more resilient supply chain functions.

The rest of this paper is structured as follows. First, a systematic literature review process is outlined. Then, a descriptive analysis of the reviewed literature is presented, and the findings related to the sub-questions are summarised. Next, a holistic model of SCRES is illustrated through a concept mapping framework, followed by a discussion of the implications for research and practice. Finally, directions for further research, arising from the study limitations, are proposed, and conclusions are drawn based on the findings. 


\section{Research Methodology: Systematic Review of SCRES Literature}

A systematic literature review (SLR) is an explicit and methodical tool with which to gain deep-seated knowledge about a given topic to inform researchers and practitioners (Briner and Denyer, 2012). Unlike traditional narrative reviews, an SLR follows a strict set of guidelines, and adopts a replicable, scientific and transparent process (Tranfield et al., 2003). It improves the clarity of scholarly communication, increases internal validity (against selection and publication bias), and creates transparency through the auditable process (Booth et al., 2012).

SLRs synthesise results based on their robust, evidence-informed approach; their power to combine evidence from existing studies can create new knowledge through rigour in the criteria for selection, the analyses and the reporting (Tranfield et al., 2003; Denyer and Tranfield, 2009). Hence, to improve methodological rigour, replicability and scholarly communication in relation to the inconsistent body of literature on SCRES, the SLR approach was taken. This study follows the five-step guidelines on conducting systematic reviews of Denyer and Tranfield (2009) (see Figure 1).

\subsection{Question Formulation}

The first step of a systematic review is to define the scope of the study (Booth et al., 2012), and to avoid ambiguity by defining and formulating the review question (Rousseau et al., 2008), as identified in the introduction section. Specifically, SCRES conceptual clarity is sought by analysing the extant literature to provide a comprehensive framework through a concept map. Hence, this study aims to answer the following review question: How can the concept of supply chain resilience be analysed to inform research and practice? To provide more insights into the review question, three sub-questions were formulated:

1. What are the constructs used to define SCRES?

2. What are the essential elements and managerial practices needed to support SCRES capabilities?

3. How can SCRES constructs be linked to improve conceptual clarity? 
Figure 1. Steps for Conducting a Systematic Literature Review

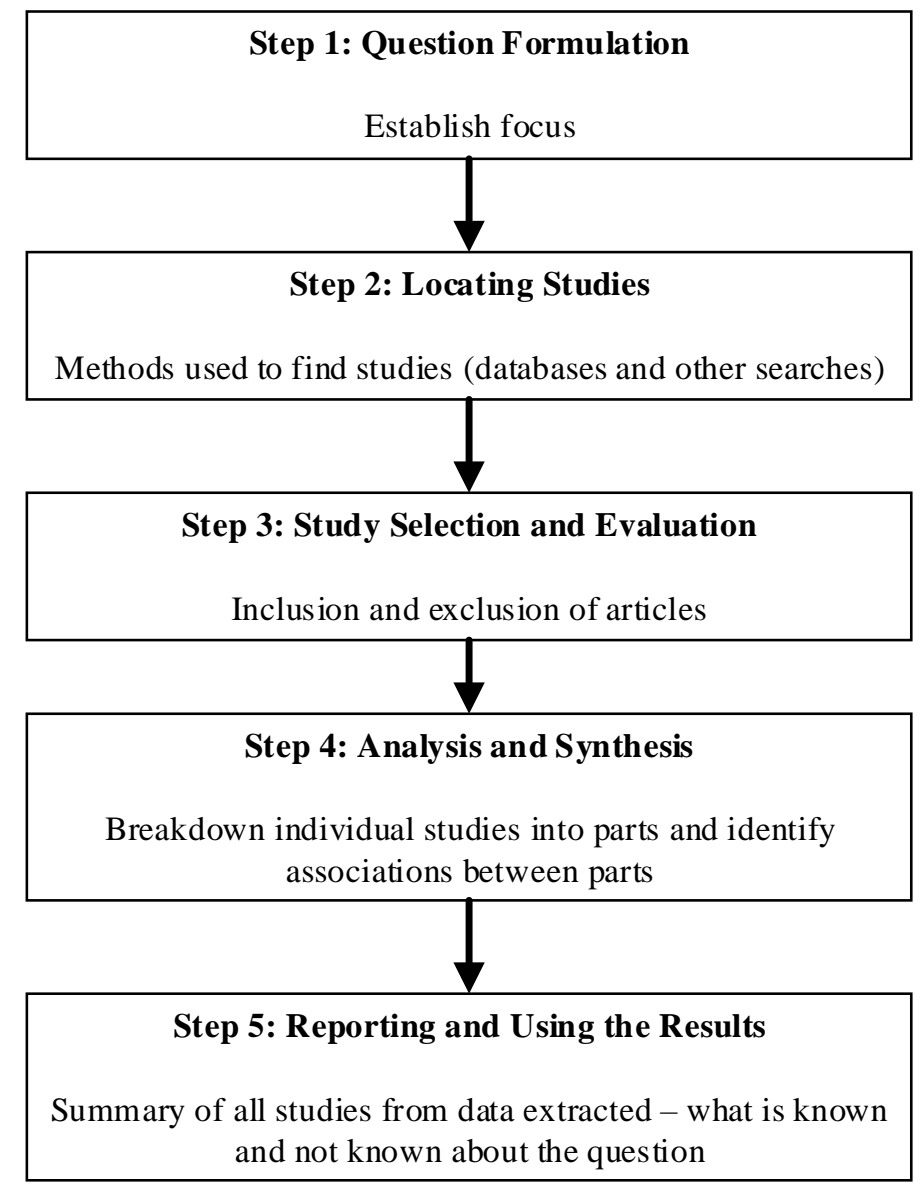

Source: Adapted from Denyer and Tranfield (2009)

\subsection{Locating Studies}

The purpose of this phase was to search through relevant journal articles to locate, select and assess contributions pertinent to the review question (Denyer and Tranfield, 2009). Several online databases were searched to minimise bias and cover a broad range of sources. The database search included EBSCO (Academic Search Complete and Business Source Complete), Emerald, Science Direct, ABI/Inform Global, Web of Knowledge and Wiley Online. These databases are considered extensive, are available at academic institutions, and have been used in similar studies (e.g. Mandal, 2014; Tukamuhabwa et al., 2015).

In line with other systematic reviews on SCRES (e.g. Pereira et al., 2014; Hohenstein et al., 2015), several defined keywords were used as search criteria. The keywords consisted of the phrase "supply chain" combined with the following keywords: "resilience," "resilient," "resiliency," "resilien*," "risk," "mitigation," "security," or "business continuity". The selected keywords were then used to construct search strings with Boolean connectors (e.g. 
AND, OR) using a combination of the search fields. For example, the phrase "supply chain" in the abstract and keyword "resilien*" OR "business continuity" in a full-text search, See Table 1. The time horizon for locating studies was from 2000 to 2015 (June). The year 2000 was selected as a starting point due to the emergence of studies on supply chain risks and vulnerability around that time (cf. Svensson, 2000). The search was first carried out in February 2015 and repeated in June 2015.

Table 1 Keywords and search strings

\begin{tabular}{llll}
\hline Construct & Keywords & Search Strings & Databases \\
\hline Supply Chain & Supply chain resilience & AB supply chain AND TX & $\bullet$ EBSCO \\
Resilience & Supply chain resiliency & (resilien* OR security OR & (Academic \\
& $\begin{array}{l}\text { Resilient supply chain } \\
\text { Supply chain security }\end{array}$ & mitigation OR business & Search Complete \\
& continuity) & and Business \\
& Risk mitigation in supply chain & & Source \\
& Business continuity of supply & AB supply chain AND TX & Complete) \\
& chain & (resilien* OR risk OR risk & - Emerald \\
& Supply chain risk & management) & - Science Direct \\
& Supply chain risk management & & - Web of \\
& & & Knowledge \\
& & & ABI/Inform \\
& & & Wiley Online \\
\hline
\end{tabular}

Note: $\mathrm{AB}=$ abstract and $\mathrm{TX}=$ all text

\subsection{Study Selection and Evaluation}

The transparency of the process was maintained through explicit selection criteria to evaluate the relevance of studies for answering the review question (Denyer and Tranfield, 2009; Booth et al., 2012). A list of inclusion criteria, as illustrated in Table 2, was used for the first screening, involving the reading of titles and abstracts of each paper. In total, 785 documents were screened at this stage. Articles that did not meet the inclusion criteria, were not relevant to the topic or were duplicates were excluded. The remaining 130 articles were identified as potential candidates for inclusion in the review process. The second screening evaluated the preliminary list through the reading of the introduction and conclusion of each paper to further assess their relevance. From this screening, 33 articles were excluded either due to them not being relevant to the topic or because the full article was unobtainable due to access restrictions.

The two screenings resulted in a total of 97 articles for undergoing full document screening. A further eight articles were identified through cross-referencing citations. Cross-referencing was carried out on specific journals that contribute to SCRES studies, but that had been 
missed by the databases search. In total, 105 articles were included in the full document screening process. Each article was fully read and analysed to address the review question. Further, quality criteria were applied to check the alignment of the paper's rationale in terms of the topic, methods and execution, methodological rigour, and contribution to knowledge (Miles and Huberman, 1994). Two articles were excluded as a result of the quality screening, leaving 103 articles for the final review process. The sample of 103 articles is denoted with an asterisk (*) in the reference list. A graphical illustration of the selection and evaluation process is provided in Figure 2.

Table 2 Inclusion criteria for SCRES systematic review

\begin{tabular}{ll}
\hline Inclusion Criteria & Rationale \\
\hline Published in peer-reviewed journals & $\begin{array}{l}\text { Peer-reviewed journals are considered to be of } \\
\text { higher quality than non-peer-reviewed articles. }\end{array}$
\end{tabular}

Selection of papers published $2000-$ $2015^{*}$

The year 2000 was selected as a starting point due to the emergence of studies on supply chain vulnerability around this time (e.g. Svensson, 2000).

Resilience addressed within the context of SCM or logistics, and is, at least, one of the focus of the paper

The aim of the review is to analyse and map the different features of SCRES to improve conceptual clarity and understanding.

Published in the English language

English is the dominant language in the field of SCM research.

Different types of article considered (e.g.

The focus of the study is to evaluate and empirical, literature review, conceptual) synthesise the various approaches to the concept of SCRES.

* Up to the end of June 2015

\subsection{Analysis and Synthesis}

The objective of this phase was to analyse and synthesise the 103 articles so as to develop new knowledge and insights about the topic (Denyer and Tranfield, 2009). An analysis was conducted by categorising each of the 103 articles in a spreadsheet and identifying/coding SCRES dimensions that are addressed in every article. The extracted data provided a comprehensive summary of SCRES and helped in classifying and synthesising the concept themes and elements. There are different approaches to synthesis in SLR such as aggregation, integration, interpretation and explanation (Rousseau et al., 2008). The integration approach 
was used because of the heterogeneous nature of the articles in this review, and since the goal was to synthesise across multiple studies and methods to answer the review question (Rousseau et al., 2008).

Figure 2 Study selection and evaluation

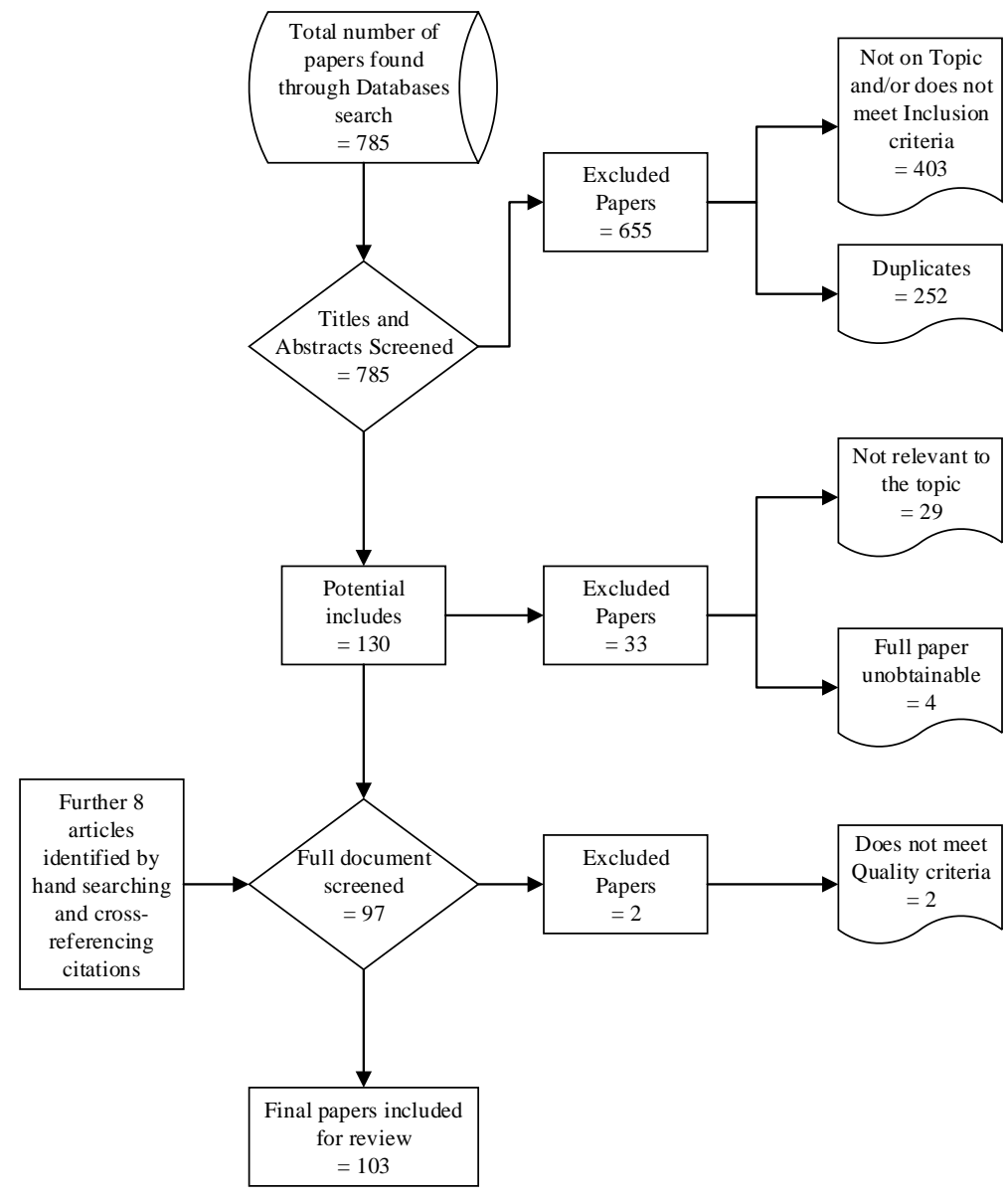

Source: Based on PRISMA flow diagram (Moher et al., 2009)

\subsection{Reporting and Using the Results}

This step provides the findings from all the selected studies, their relation to each other, and what is known and not known about the review question (Denyer and Tranfield, 2009). The subsequent synthesis is an informed interpretation of the scientific evidence relating to the research question and the gaps found in the review process (Rousseau et al., 2008). The following section outlines these findings on the current state of SCRES studies and the results relating to the three sub-questions.

\section{Findings}

The SLR findings are reported in four sections, each of which will advance the understanding of the concept of SCRES. First, to understand the developments in SCRES literature, a 
descriptive analysis of the 103 articles is presented below, detailing the publication year, the relevant academic journals, and the methodological approach. Second, SCRES definitions are analysed to evaluate SCRES phases, strategies and capabilities so as to answer the first subquestion. Third, to address sub-question two, essential elements and managerial practices that support SCRES capabilities are examined. Finally, a holistic model is proposed to improve conceptual clarity by integrating SCRES constructs emerging from the SLR. The model is presented through a concept mapping framework that visually illustrates the relationships between the concept's constructs, and highlights the best practices for achieving a resilient supply chain.

\subsection{Descriptive Analysis}

Even though the time horizon for the selection of papers for this study started in 2000, the first article found to address the concept of SCRES was by Rice and Caniato, in 2003. Although other reviews on SCRES have reported papers from 2000 (e.g. Pereira et al., 2014), none of these (e.g. Christopher, 2000; Sheffi, 2001) mentioned the term SCRES explicitly before the year 2003. Instead, research on the concept of SCRES started as a follow-up to two significant report findings on supply chain responses to terrorism (MIT Center for Transportation and Logistics, 2003); and Cranfield University (2003) on creating resilient supply chains. In fact, the work of Rice and Caniato (2003), Christopher and Peck (2004), and Sheffi and Rice (2005), which forms the foundation of the SCRES literature, is based on the findings from these reports. Their research has influenced and motivated other studies on SCRES, leading to a steady growth of articles in the SCM domain. Figure 3 shows that most SCRES articles were published between 2009 and 2015, providing evidence for the growing body of literature and the importance of SCRES in maintaining business continuity and competitiveness. This observation is also emphasised by Pereira et al. (2014), Mandal (2014) and Hohenstein et al. (2015).

The 103 articles were published in 43 interdisciplinary academic journals. More than half of the articles (53) were published in eight leading journals in the field of SCM (see Table 3). The highest share of studies in these leading journals was published in the International Journal of Production Research and Supply Chain Management: An International Journal. The diversity of the journals' research themes (i.e. production research, business logistics, operations management, and supply chain management) is evidence of the multidisciplinary 
nature of the topic and the increasing attention it is attracting from various research communities.

Figure 3 Number of studies on SCRES 2003-2015*

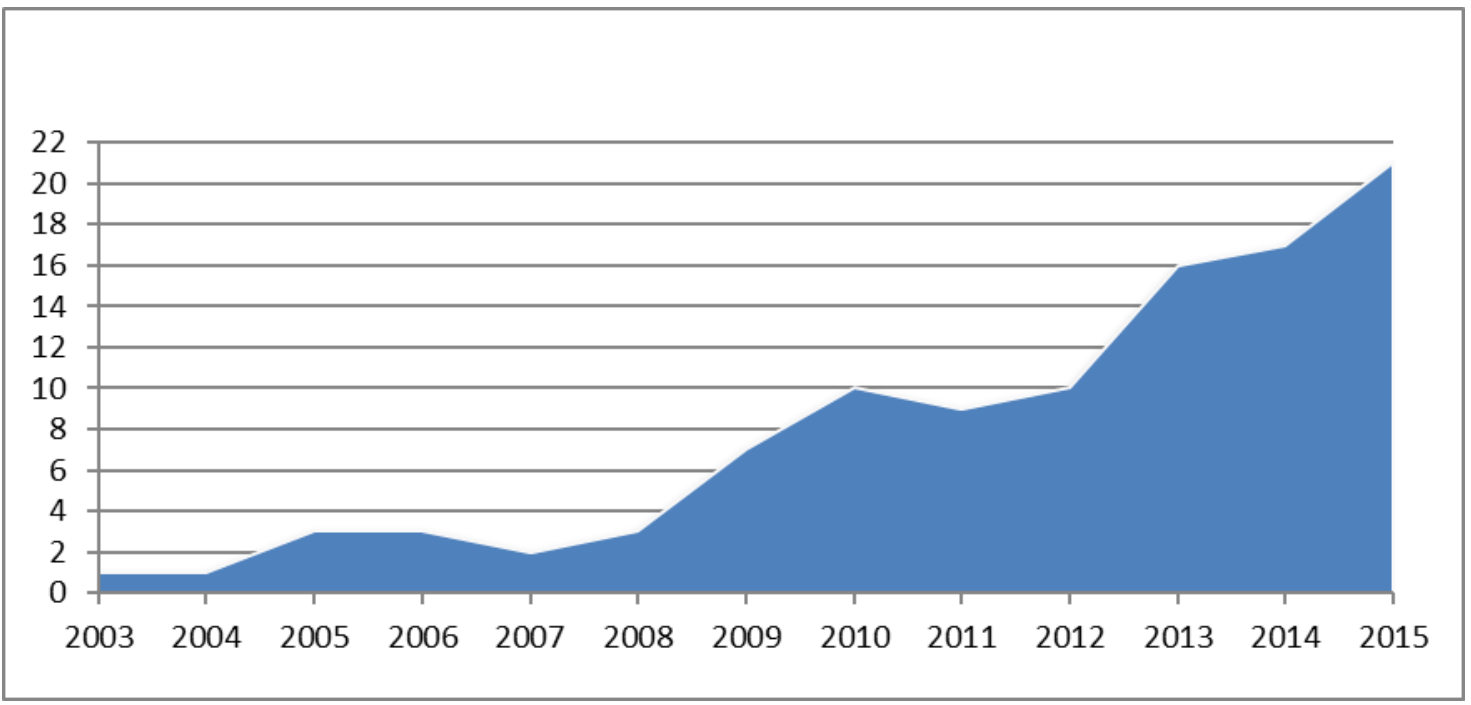

* Based on the final results of the SLR in this study

Table 3 Number of articles published in academic journals

\begin{tabular}{lcc}
\hline Academic Journal & $\begin{array}{c}\text { No. of } \\
\text { Papers }\end{array}$ & Percentage \\
\hline International Journal of Production Research & 12 & $11.65 \%$ \\
Supply Chain Management: An International Journal & 11 & $10.68 \%$ \\
International Journal of Physical Distribution \& Logistics & & \\
Management & 6 & $5.83 \%$ \\
Journal of Business Logistics & 6 & $5.83 \%$ \\
International Journal of Logistics: Research \& Applications & 5 & $4.85 \%$ \\
International Journal of Production Economics & 5 & $4.85 \%$ \\
MIT Sloan Management Review & 5 & $4.85 \%$ \\
Journal of Operations Management & 3 & $2.91 \%$ \\
Others & 50 & $48.54 \%$ \\
\hline
\end{tabular}

In the literature, various research methodologies have been used to address the topic of SCRES. Based on Figure 4, five methodologies are common across the 103 reviewed articles: theoretical and conceptual papers (20), case studies (21), simulation/modelling papers (21), literature reviews (21) and surveys (13). The remainder used mixed-methods (3) and secondary data (4) methodologies. Although the use of multiple methods was applied in some studies (e.g. Craighead et al., 2007; Azevedo et al., 2013), each article in this instance was 
classified under the primary methodology. For example, Craighead et al. (2007) applied multiple methods - involving a case study, semi-structured interviews and a focus group - in their study, but this article was classified under "case study" because this was the primary method used. The analysis indicates that few articles used mixed-method research despite its rigorous approach to in-depth and wider analysis of a concept such as SCRES. Since SCRES is a complex and multidimensional research subject, a mix of empirical and analytical research methods is needed to develop the theory and evaluate its implementation.

Figure 4 Classification of SCRES methodologies

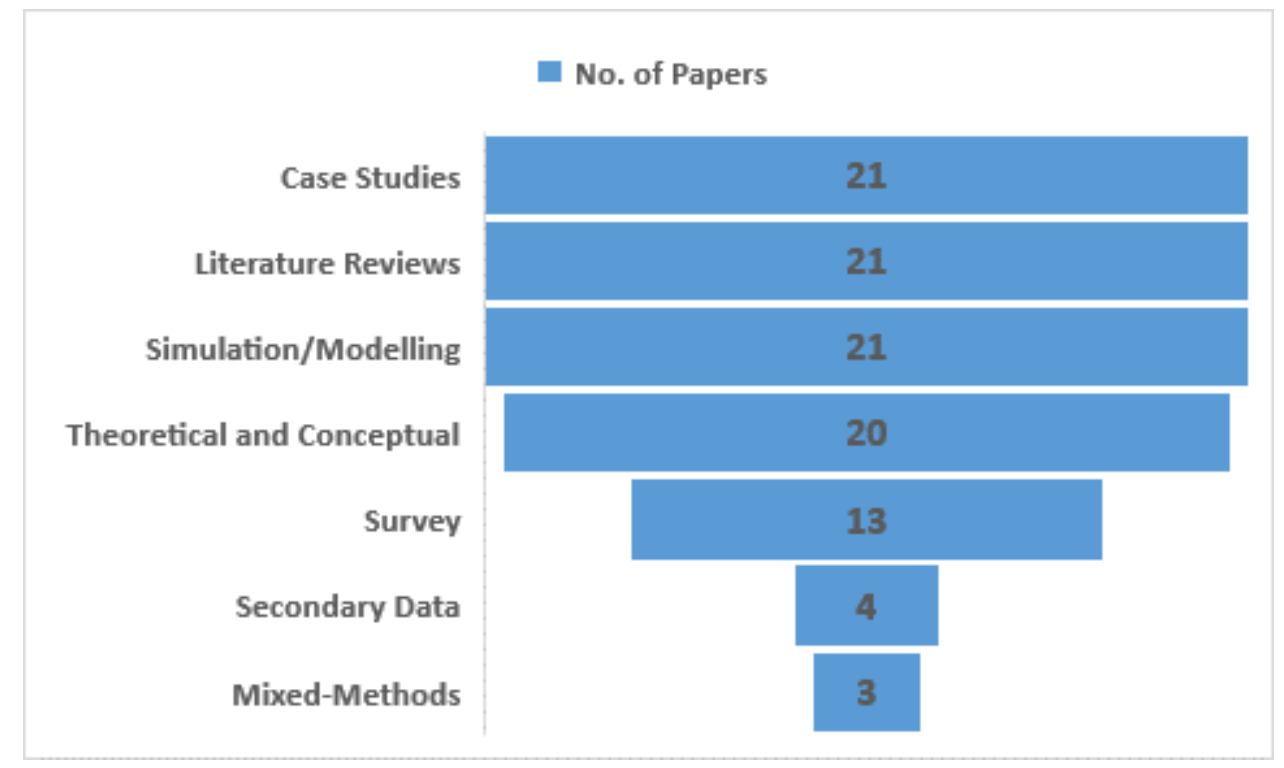

\subsection{Analysis of SCRES Definitions}

Resilience is considered one of the fundamental attributes that supply chains need to embrace to efficiently cope with disruptive events (Rice and Caniato, 2003; Christopher and Peck, 2004). The concept of SCRES appears to offer a way to avoid the limitations of traditional approaches to risk prevention and protection strategies, and to deal with the complexities of global supply chains (Pettit et al., 2013; Sheffi, 2015). The idea of resilience, however, according to Walker and Salt (2012) is wide-ranging, and has its origin in the fields of engineering (cf. Hollnagel et al., 2006), psychology (cf. Luthar et al., 2000), ecology (cf. Holling, 1973) and disaster relief (cf. Manyena, 2006). Indeed, several resilience aspects from these domains have been borrowed by the SCM field to define SCRES (e.g. Sheffi and Rice, 2005; Ponomarov and Holcomb, 2009). 
Table 4 (abridged) shows the diversity of SCRES definitions in the selected studies of the reviewed literature based on their contributions to advancing SCRES knowledge (for the remainder, see Table 1A, Appendix A). These definitions address the concept on three different levels: from a firm, network, and system-wide perspective. Overall, the definitions either were adapted from previous studies, or aspects of resilience from other disciplines (such as psychology, ecology, engineering) were borrowed to form part of the definition of SCRES. The analysis of the definitions (Table 4; Table 1A) identified three constructs in most definitions: the phases of resilience, resilience strategies, and the capabilities needed for resilience. The following sections analyse, synthesise and interpret each of these constructs.

\subsubsection{Phases of SCRES}

The first construct relates to the three phases of SCRES, which cover the moments of predisruptions, during-disruption, and post-disruptions (Sheffi and Rice, 2005). To examine these phases, the themes that characterised them in each definition were highlighted. Themes such as prepare, resist, avoid and alert are used to describe the pre-disruption phase (Table 4), while themes such as respond, cope and adapt refer to the during-disruption phase, and themes such as recover, survive, restore and return describe the post-disruption phase. A chronological order of SCRES definitions shows that the initial focus on the concept was response (during-disruption phase) and recovery (post-disruption phase) in adversity. For example, Rice and Caniato's (2003) definition centres on the ability to react and restore normal operations; Christopher and Peck's (2004) on the system's ability to return or move to a new state through adaptability, whereas that of Sheffi and Rice (2005) focuses on the notion of 'bouncing back' from disruption. Peck (2006) highlights the ability to absorb or mitigate disturbances, whereas Datta et al. (2007) put the stress not only on maintaining control but also on adaptation and response.

Over time, the emphasis in defining SCRES shifted from supply chain ability to respond and recover to include elements of resilience-preparation and growth, as shown in Figure 5. The first definition to highlight preparation (pre-disruption phase) for unexpected events was developed by Ponomarov and Holcomb (2009), and was followed by the similar theme of anticipation (Ponis and Koronis, 2012; Day, 2014). Similarly, the idea of seeking growth through opportunities that may emerge in the post-disruption phase was reflected in themes such as grow/growth and thrive that formed part of certain definitions (Pettit et al., 2010; Johnson et al., 2013; Hohenstein et al., 2015), thus encompassing all three phases of resilience. However, only 10 out of the 59 reviewed definitions incorporated all three phases, 
which indicates that further theoretical development of the concept is needed to consolidate the major phases.

Table 4 SCRES definitions

\begin{tabular}{|c|c|}
\hline Authors & SCRES Definitions \\
\hline $\begin{array}{l}\text { Rice and Caniato } \\
(2003, \text { p. } 25)\end{array}$ & $\begin{array}{l}\text { Resilience is widely used to characterize an organization's ability to react to } \\
\text { an unexpected disruption, such as one caused by a terrorist attack or a natural } \\
\text { disaster, and restore normal operations. }\end{array}$ \\
\hline $\begin{array}{l}\text { Christopher and Peck } \\
(2004, \text { p. 2) }\end{array}$ & $\begin{array}{l}\text { The ability of a system to return to its original state or move to a new, more } \\
\text { desirable state after being disturbed. }\end{array}$ \\
\hline $\begin{array}{l}\text { Sheffi and Rice } \\
(2005, p .41)\end{array}$ & The ability to bounce back from a disruption. \\
\hline $\begin{array}{l}\text { Datta et al. } \\
\text { (2007, p. 189) }\end{array}$ & $\begin{array}{l}\text { Supply chain resilience is defined as not only the ability to maintain control } \\
\text { over performance variability in the face of disturbance, but also as a property } \\
\text { of being adaptive and capable of sustained response to sudden and significant } \\
\text { shifts in the environment in the form of uncertain demands. }\end{array}$ \\
\hline $\begin{array}{l}\text { Ponomarov and } \\
\text { Holcomb } \\
(2009 \text {, p. 131) }\end{array}$ & $\begin{array}{l}\text { The adaptive capability of the supply chain to prepare for unexpected events, } \\
\text { respond to disruptions, and recover from them by maintaining continuity of } \\
\text { operations at the desired level of connectedness and control over structure } \\
\text { and function. }\end{array}$ \\
\hline $\begin{array}{l}\text { Klibi et al. } \\
(2010 \text {, p. } 287)\end{array}$ & $\begin{array}{l}\text { "... resilience is the capability of a SCN to avoid disruptions or quickly } \\
\text { recover from failures." }\end{array}$ \\
\hline $\begin{array}{l}\text { Pettit et al. } \\
(2010, \text { p. } 1)\end{array}$ & $\begin{array}{l}\text { The adaption and growing of the capacity for enterprise to survive in the face } \\
\text { of turbulent change. }\end{array}$ \\
\hline $\begin{array}{l}\text { Jüttner and Maklan } \\
(2011, \text { p. 247) }\end{array}$ & $\begin{array}{l}\text { Supply chain resilience addresses the supply chain's ability to cope with the } \\
\text { consequences of unavoidable risk events in order to return to its original } \\
\text { operations or move to a new, more desirable state after being disturbed. }\end{array}$ \\
\hline $\begin{array}{l}\text { Blackhurst et al. } \\
(2011, \text { p. 374) }\end{array}$ & Supply chain resilience is a firm's ability to recover from disruptive events. \\
\hline $\begin{array}{l}\text { Ponis and Koronis } \\
(2012 \text {, p. } 925-6)\end{array}$ & $\begin{array}{l}\text { The ability to proactively plan and design the Supply Chain network for } \\
\text { anticipating unexpected disruptive (negative) events, respond adaptively to } \\
\text { disruptions while maintaining control over structure and function and } \\
\text { transcending to a post-event robust state of operations, if possible, more } \\
\text { favorable than the one prior to the event, thus gaining competitive advantage. }\end{array}$ \\
\hline $\begin{array}{l}\text { Wieland and } \\
\text { Wallenburg } \\
(2013, \text { p. } 301)\end{array}$ & $\begin{array}{l}\text { In this research, resilience is understood as the ability of a supply chain to } \\
\text { cope with change. }\end{array}$ \\
\hline $\begin{array}{l}\text { Melnyk et al. } \\
\text { (2014, p. 36) }\end{array}$ & $\begin{array}{l}\text { The ability of a supply chain to both resist disruptions and recover } \\
\text { operational capability after disruptions occur. }\end{array}$ \\
\hline Day (2014, p. 3) & $\begin{array}{l}\text { Resilience is 'the capability to anticipate risk, limit impact, and bounce back } \\
\text { rapidly through survival, adaptability, evolution, and growth in the face of } \\
\text { turbulent change'. }\end{array}$ \\
\hline $\begin{array}{l}\text { Hohenstein et al. } \\
(2015, \text { p. 108) }\end{array}$ & $\begin{array}{l}\text { Supply chain's ability to be prepared for unexpected risk events, responding } \\
\text { and recovering quickly to potential disruptions to return to its original } \\
\text { situation or grow by moving to a new, more desirable state in order to } \\
\text { increase customer service, market share and financial performance. }\end{array}$ \\
\hline $\begin{array}{l}\text { Ambulkar et al. } \\
(2015, \text { p. } 112)\end{array}$ & $\begin{array}{l}\text { Firm's resilience to supply chain disruptions is defined as the capability of } \\
\text { the firm to be alert to, adapt to, and quickly respond to changes brought by a } \\
\text { supply chain disruption. }\end{array}$ \\
\hline
\end{tabular}


Figure 5 SCRES phases timeline in definitions

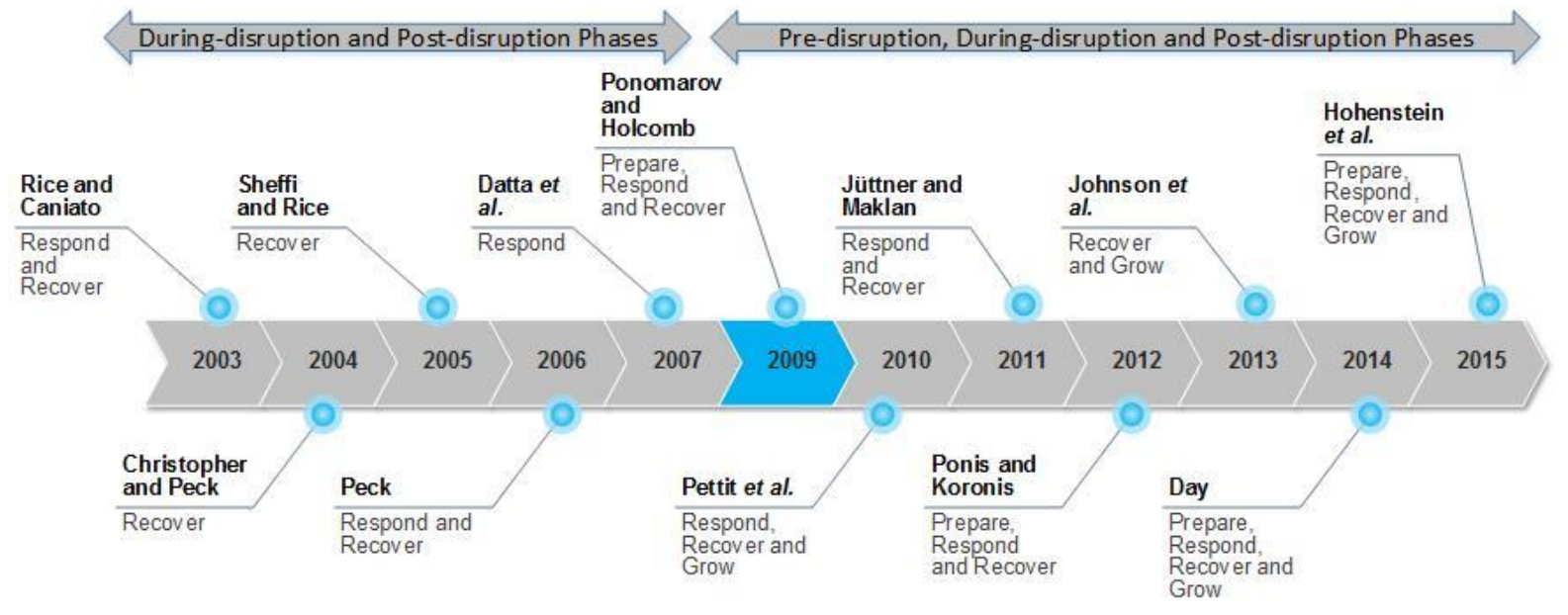

\subsubsection{SCRES Strategies}

The second construct addressed in most of the definitions is the strategy used to prepare for, respond to and recover from supply chain disruptions. These strategies can be classified into three main categories: proactive, concurrent, and reactive (Hollnagel, 2011). Proactive strategies refer to competencies needed in the pre-disruption phase; key themes in the definitions are plan, anticipate, alert and prepare (Ponomarov and Holcomb, 2009; Day, 2014; Ambulkar et al., 2015). Concurrent strategies, on the other hand, relate to quick reactive thinking and first-response abilities to cope with disturbances in the duringdisruptions phase (Sheffi and Rice, 2005; Hollnagel, 2011). Themes such as cope with change, adapt and respond to unexpected events (Knemeyer et al., 2009; Carvalho et al., 2011; Wu et al., 2013) imply a concurrent strategy. Finally, reactive strategies refer to what is required in the post-disruption phase so as to recover; the recurring themes in the definitions are bounce back from disruption and return to the original or desired state (Schmitt and Singh, 2012; Brandon-Jones et al., 2014; Urciuoli, 2015).

Although proactive and reactive strategies are explicitly discussed in the SCRES literature, concurrent strategies are implicitly referred to. For example, Sheffi and Rice (2005) referred to the concurrent strategies as a first response, while Scholten et al. (2014) discussed them under immediate response. One plausible explanation could be that, in most SCRES literature, concurrent strategies are classified under, and sometimes considered part of, reactive strategy. In practice, however, these strategies are different; concurrent strategies 
consist of rapid adjustments of the system during disruption, whereas reactive strategies take place in the aftermath of an event (Hollnagel, 2011).

\subsubsection{SCRES Capabilities}

The third construct used to define SCRES relates to the capability required to be resilient. Despite the diversity in SCRES definitions, the reviewed literature shares common capabilities through which firms can effectively manage disruptions and/or a changing environment. Based on SCRES definitions in Table 4 and Table 1A, various themes that convey common terms of resilience capabilities were coded and grouped. Four main groups were identified based on Hollnagel's (2011) taxonomy for safety science resilience capabilities: the ability to anticipate, to monitor, to respond, and to learn. Three of the four capabilities (ability to anticipate, respond and learn) were actively supported by common themes in the definitions. Surprisingly, despite it being important for firms to monitor supply chain performance before, during and after disruption, only the Ambulkar et al. (2015) definition referred to monitoring capability. One explanation for this could be that most authors adapt previous definitions, and thus SCRES definitions change slightly over time (Hohenstein et al., 2015). Another explanation may be that monitoring capabilities are seen as part of the ability to anticipate, and are thus tacitly referred to by other similar terms such as preparing and planning. In this study, the capacity to monitor as an integral part of the ability to anticipate is considered. Building on Hollnagel's classification of resilience capabilities, the reviewed definitions reveal two more significant SCRES capabilities that can support a firm in developing a resilient supply chain: the ability to adapt, and to recover.

Table 5 summarises the five SCRES capabilities derived from the reviewed definitions. It indicates that the emphasis in the current literature is on the ability to recover and adapt, while scant attention is paid to the capacity to learn from experience. The results support the suggestion that SCRES research needs to address the broader role of proactive capabilities (Knemeyer et al., 2009; Wieland and Wallenburg, 2013) and learning capabilities in building SCRES (Blackhurst et al., 2011; Jüttner and Maklan, 2011). 
Table 5 SCRES capabilities

\begin{tabular}{|c|c|c|c|}
\hline $\begin{array}{l}\text { SCRES } \\
\text { Capabilities }\end{array}$ & Description & Themes in SCRES Definitions & $\begin{array}{l}\text { No. of } \\
\text { papers }\end{array}$ \\
\hline $\begin{array}{l}\text { Ability to } \\
\text { Anticipate }\end{array}$ & $\begin{array}{l}\text { Proactive capabilities necessary to } \\
\text { identify and monitor potential events, } \\
\text { changing environments, and } \\
\text { performance before the ability of the } \\
\text { supply chain to function is affected }\end{array}$ & $\begin{array}{l}\text { Proactively plan, anticipate risk, } \\
\text { prepare, resist, avoid, and be alert }\end{array}$ & 14 \\
\hline $\begin{array}{l}\text { Ability to } \\
\text { Adapt }\end{array}$ & $\begin{array}{l}\text { Concurrent capabilities required to } \\
\text { manage and adjust critical supply } \\
\text { chain resources continually during } \\
\text { disruptions and/or normal business } \\
\text { activities }\end{array}$ & $\begin{array}{l}\text { Cope with unexpected } \\
\text { disturbance or change, } \\
\text { absorb/withstand/reduce impact, } \\
\text { tolerate, adapt }\end{array}$ & 29 \\
\hline $\begin{array}{l}\text { Ability to } \\
\text { Respond }\end{array}$ & $\begin{array}{l}\text { Concurrent capabilities needed to } \\
\text { react to supply chain events on time } \\
\text { and efficiently, to lessen the impact } \\
\text { of disruptions or change the effects } \\
\text { to ensure a desirable outcome }\end{array}$ & $\begin{array}{l}\text { Maintain control, retain structure } \\
\text { and function, react, change } \\
\text { rapidly, and respond }\end{array}$ & 19 \\
\hline $\begin{array}{l}\text { Ability to } \\
\text { Recover }\end{array}$ & $\begin{array}{l}\text { Reactive capabilities essential in the } \\
\text { aftershock of a supply chain event, so } \\
\text { as to restore or return to normal } \\
\text { operations }\end{array}$ & $\begin{array}{l}\text { Survive, maintain continuity, } \\
\text { bounce back, return to } \\
\text { original/normal state, move to } \\
\text { new/desirable state, recover, } \\
\text { restore quickly, in timely fashion, } \\
\text { and cost-effectively, and resume } \\
\text { operations }\end{array}$ & 48 \\
\hline $\begin{array}{l}\text { Ability to } \\
\text { Learn }\end{array}$ & $\begin{array}{l}\text { Reactive capabilities required after a } \\
\text { supply chain event to understand } \\
\text { what has happened and improve } \\
\text { future performance based on the } \\
\text { experience }\end{array}$ & $\begin{array}{l}\text { Sustain, growth, thrive, evolve, } \\
\text { future adjustments, and } \\
\text { profitability }\end{array}$ & 10 \\
\hline
\end{tabular}

In summary, the three constructs described above can help map definitions of SCRES through their phases, strategies and capabilities, as illustrated in Figure 6. Narrow definitions of SCRES in the literature can pertain to aspects of one or two phases and strategies of resilience, whereas a broad definition encompasses all three phases and strategies. Furthermore, the analysis of SCRES definitions indicates that more refined constructs are warranted, since the alignment among SCRES capabilities, resilient phases and strategies lacks clarity. As such, the aim here is to highlight such ambiguities to enhance future clarity on definitions, and not to adapt or provide a new SCRES definition. The examination of SCRES definitions has helped to bridge this gap by mapping the relations between SCRES capabilities and its strategies and phases, as outlined in Figure 6. 
Figure 6 Three constructs of SCRES definitions

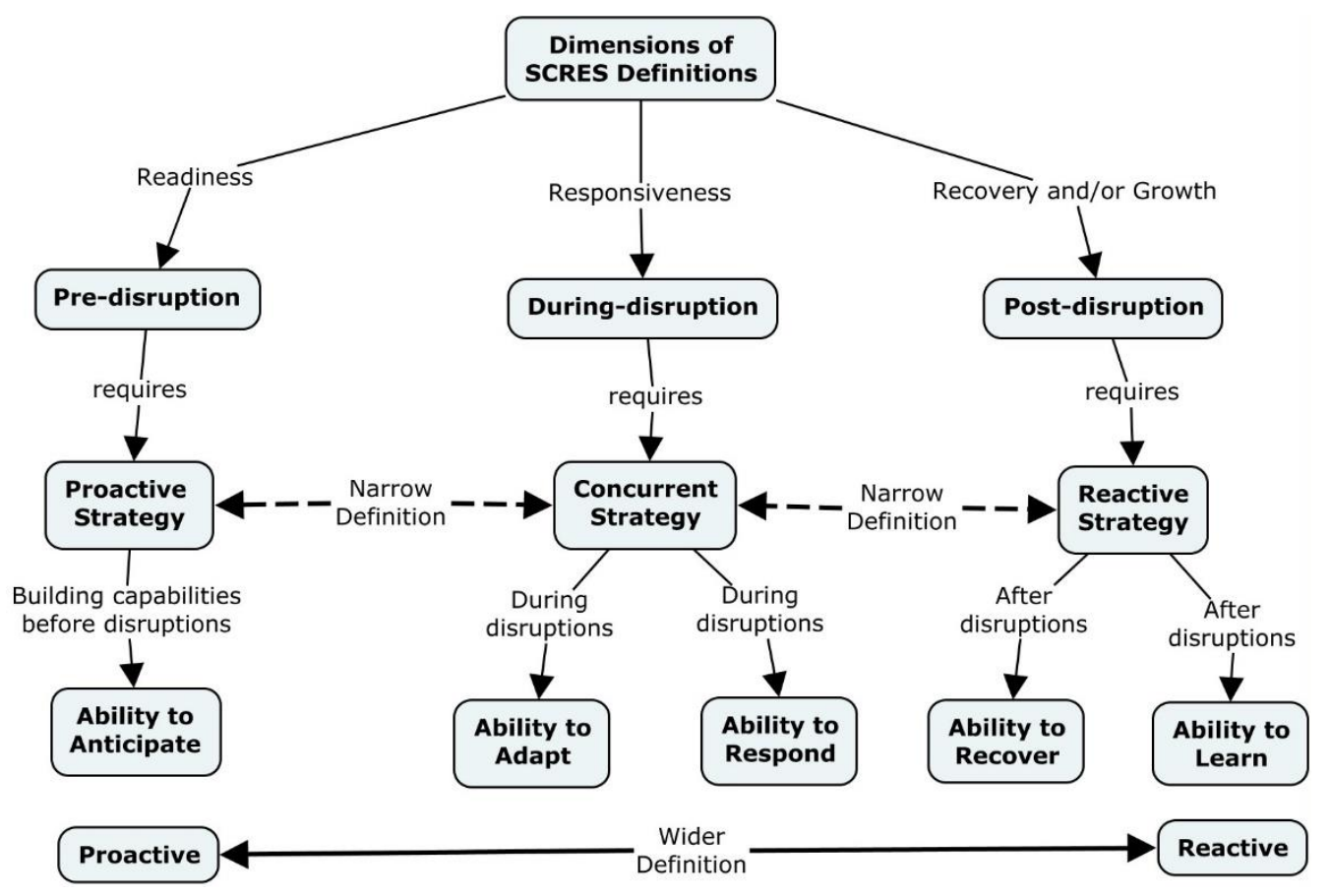

\subsection{Elements and Managerial Practices of SCRES Capabilities}

In evaluating the elements that build SCRES capabilities, an array of terms is found in the literature that describes this attribute. These include terminologies such as dimensions (Aigbogun et al., 2014), capabilities (Pettit et al., 2013), enhancers (Blackhurst et al., 2011), enablers (Pereira et al., 2014) and elements (Christopher and Peck, 2004). Antecedents (Scholten and Schilder, 2015), principles (Seville et al., 2015) and competencies (Wieland and Wallenburg, 2013) have been used to describe features of SCRES. These differences explain the divergence in how resilience is understood, investigated and applied in the SCM context. Indeed, many researchers have argued that the body of knowledge on SCRES is fragmented, lacks conceptual clarity and is in need of better theory-building to advance the topic (Ponomarov and Holcomb, 2009; Bhamra et al., 2011). Despite the growing body of literature on SCRES, as shown in Figure 3, these issues are not consistently addressed.

Hence, to bring consistency to the terminology, this study, consistently with the Christopher and Peck (2004) and Hohenstein et al. (2015) analysis of SCRES attributes, refers to them as elements. The systematic review of the SCRES literature identified 27 elements (see Figure 7). The largest number of studies addressed supply chain network design through configuration (38) and building flexibility (37). Other essential elements such as redundancy 
(30), visibility (29), collaboration (23) and agility (21) were also discussed in the literature. For the complete list of 27 elements and their corresponding authors, see Table 2B, Appendix B.

Figure 7 Elements supporting SCRES capabilities

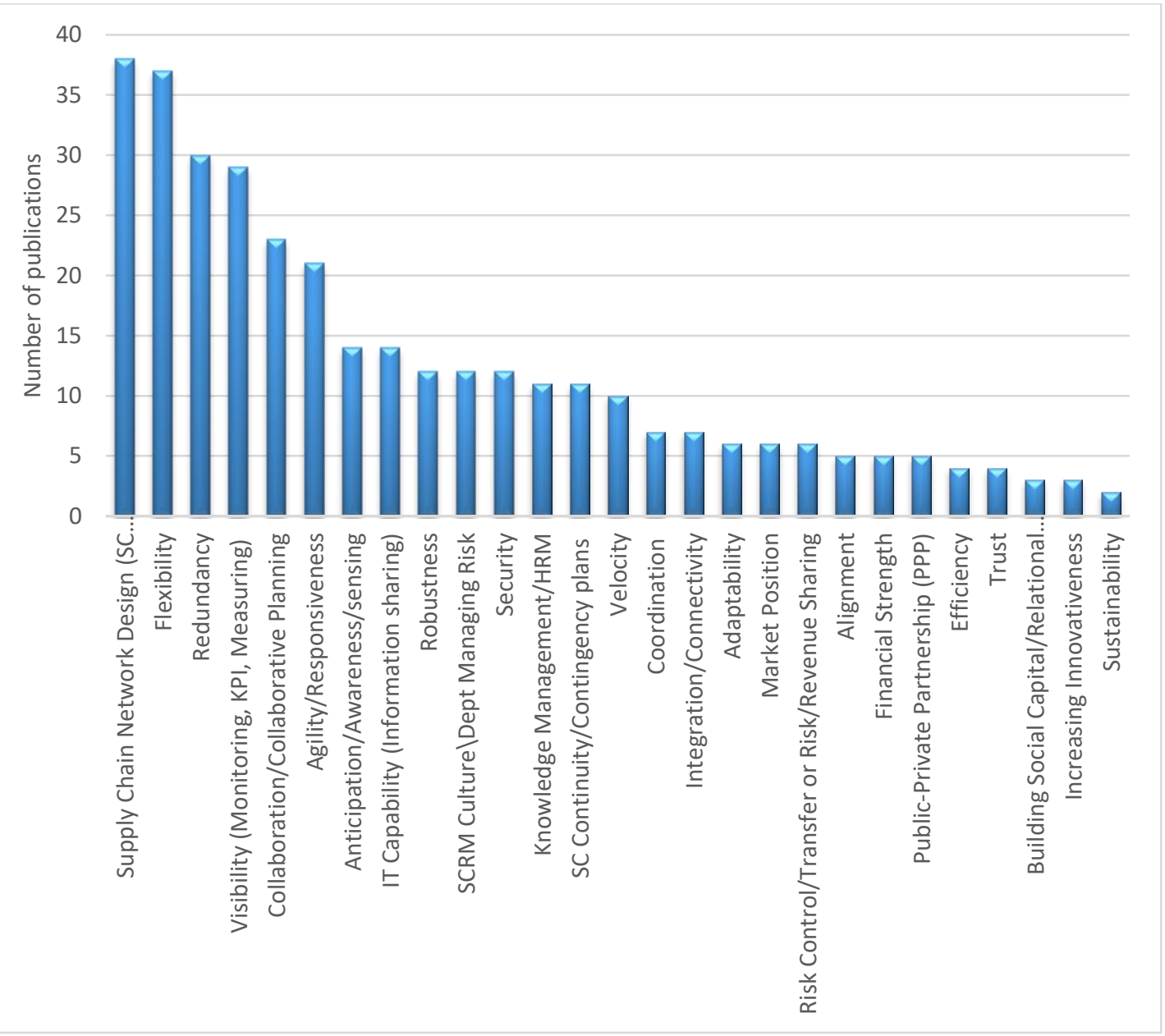

The analysis of elements that support SCRES capabilities reveals the disparity in the way these elements are grouped in the literature. For example, some authors regard velocity and visibility as an antecedent of achieving agility (Christopher and Peck, 2004; Jüttner and Maklan, 2011). In contrast, the study by Pettit et al. (2013) found visibility to be an important element in enhancing SCRES capabilities through information exchange and business intelligence. Similarly, previous reviews on SCRES studies have grouped and classified elements into their corresponding sub-elements and/or strategies (e.g. Hohenstein et al., 2015; Tukamuhabwa et al., 2015). In this study, the term managerial practice is used to indicate sub-elements that operate at the operational level of the concept's abstract to build SCRES capabilities. 
To seek clarity and improve understanding of SCRES elements, there is a need to consolidate supply chain resilient elements and their practices, and link them to the SCRES phases, strategies and capabilities. Based on the 27 elements (Table 2B), 13 essential elements and their matching practices are selected to support the five SCRES capabilities (Table 5). The 13 elements are selected based on rigorous previous studies (e.g. Blackhurst et al., 2011; Pettit et $a l ., 2013$ ) and reviews grounded in theory (e.g. Ponomarov and Holcomb, 2009; Pereira et al., 2014). Further, these elements and practices are then linked with their related SCRES capabilities and strategies, as shown in Table 6. This establishes the connections that provide an integrated view of SCRES, allowing the concept to develop and progress, and promoting further advances in the field. 
Table 6 An integrated view of SCRES constructs

\begin{tabular}{|c|c|c|c|c|}
\hline Strategy & Capability & Elements & Practices & Authors \\
\hline \multirow{5}{*}{ Proactive } & \multirow{5}{*}{$\begin{array}{l}\text { Ability to } \\
\text { Anticipate }\end{array}$} & $\begin{array}{l}\text { Situation } \\
\text { Awareness }\end{array}$ & $\begin{array}{l}\text { Sensing and interpreting events, continuity planning, mapping of supply chain } \\
\text { vulnerabilities, warning strategies, risk avoidance and containment, risk } \\
\text { control/transfer/share }\end{array}$ & $\begin{array}{l}\text { Manuj and Mentzer (2008), Melnyk et al. (2010), Pettit et al. } \\
\text { (2010), Kumar and Sosnoski (2011), Sawik (2013), Sáenz and } \\
\text { Revilla (2014), Ambulkar et al. (2015), Seville et al. (2015) }\end{array}$ \\
\hline & & Robustness & $\begin{array}{l}\text { Supply chain network design \& infrastructure, segmentation, decentralisation, } \\
\text { density, complexity, node/location criticality, product flow, product design, supply } \\
\text { base strategy, anticipation/preparedness to changes }\end{array}$ & $\begin{array}{l}\text { Tang (2006), Knemeyer } \text { et al. (2009), Klibi } \text { et al. (2010), Khan } \\
\text { et al. (2012), Wieland and Wallenburg (2013), Chopra and } \\
\text { Sodhi (2014), Scholten } \text { et al. (2014), Durach } \text { et al. (2015) }\end{array}$ \\
\hline & & $\begin{array}{l}\text { Increasing } \\
\text { Visibility }\end{array}$ & $\begin{array}{l}\text { Monitoring performance (KPI metric and measurement), IT capabilities, } \\
\text { information-sharing, transparency through integrated systems, connectivity }\end{array}$ & $\begin{array}{l}\text { Pereira (2009), Ponomarov and Holcomb (2009), Brandon- } \\
\text { Jones et al. (2014), Day (2014), Melnyk et al. (2014), Fiksel et } \\
\text { al. (2015) }\end{array}$ \\
\hline & & Building Security & $\begin{array}{l}\text { Freight/physical security, security culture, countermeasures for counterfeiting } \\
\text { threat, cyber-security, layered defences, creating Public-Private Partnerships (PPP), } \\
\text { cooperative strategies with supply chain partners }\end{array}$ & $\begin{array}{l}\text { Sarathy (2006), Bakshi and Kleindorfer (2009), Stewart et al. } \\
\text { (2009), Williams et al. (2009), Pettit et al. (2010, 2013), Voss } \\
\text { and Williams (2013), Melnyk et al. (2014), Stevenson and } \\
\text { Busby (2015) }\end{array}$ \\
\hline & & $\begin{array}{l}\text { Knowledge } \\
\text { management } \\
\text { (Pre-disruption) }\end{array}$ & $\begin{array}{l}\text { Supply chain understanding, education and training, supply chain drills, simulations } \\
\text { and exercises, SCRM/SCRES culture, board-level leadership, risk-management } \\
\text { department, risk awareness, inter-organisational learning }\end{array}$ & $\begin{array}{l}\text { Rice and Caniato (2003), Pettit et al. (2013), Blackhurst et al. } \\
\text { (2011), Jüttner and Maklan (2011), Seville et al. (2015), } \\
\text { Stevenson and Busby (2015) }\end{array}$ \\
\hline \multirow{4}{*}{ Concurrent } & \multirow{2}{*}{$\begin{array}{l}\text { Ability to } \\
\text { Adapt }\end{array}$} & $\begin{array}{l}\text { Increasing } \\
\text { flexibility }\end{array}$ & $\begin{array}{l}\text { Flexible supply via multiple suppliers, flexible manufacturing processes or } \\
\text { resources, flexible product via postponement, flexible pricing via responsive } \\
\text { pricing, flexible transportation mode, flexibility in order fulfilment }\end{array}$ & $\begin{array}{l}\text { Sheffi and Rice (2005), Pettit et al. (2013), Yang and Yang } \\
\text { (2010), Zsidisin and Wagner (2010), Ishfaq (2012), Azevedo } \\
\text { et al. (2013), Melnyk et al. (2014), Fiksel } \text { et al. (2015 }\end{array}$ \\
\hline & & $\begin{array}{l}\text { Building } \\
\text { redundancy }\end{array}$ & $\begin{array}{l}\text { Excess capacity in production or transportation or resources, multiple suppliers, } \\
\text { safety stock, strategic inventory, emergency backup/storage facilities, low capacity } \\
\text { utilisation }\end{array}$ & $\begin{array}{l}\text { Rice and Caniato (2003), Datta } \text { et al. (2007), Ratick et al. } \\
\text { (2008), Carvalho } \text { et al. (2011), Klibi and Martel (2012), Wu et } \\
\text { al. (2013), Azadeh } \text { et al. (2014), Ambulkar } \text { et al. (2015) }\end{array}$ \\
\hline & \multirow{2}{*}{$\begin{array}{l}\text { Ability to } \\
\text { Respond }\end{array}$} & Collaboration & $\begin{array}{l}\text { Collaborative planning, supply chain intelligence, information-sharing, } \\
\text { coordination, coopetition with competitors }\end{array}$ & $\begin{array}{l}\text { Christopher and Peck (2004), Leat and Revoredo-Giha (2013), } \\
\text { Scholten } \text { et al. (2014), Fiksel } \text { et al. (2015), Scholten and } \\
\text { Schilder (2015) }\end{array}$ \\
\hline & & Agility & Velocity and acceleration, responsiveness, speed & $\begin{array}{l}\text { Tang and Tomlin (2008), Ismail et al. (2011), Cabral et al. } \\
\text { (2012), Ivanov et al. (2014), }\end{array}$ \\
\hline \multirow{4}{*}{ Reactive } & \multirow{2}{*}{$\begin{array}{l}\text { Ability to } \\
\text { Recover }\end{array}$} & $\begin{array}{l}\text { Contingency } \\
\text { planning }\end{array}$ & $\begin{array}{l}\text { Supply chain reconfiguration, resource reconfiguration, resource mobilisation, } \\
\text { recovery plans, restoration plans, time to market, scenario analysis }\end{array}$ & $\begin{array}{l}\text { Craighead et al. (2007), Blos et al. (2010), Colicchia et al. } \\
(2010), \text { Gong et al. (2014), Ambulkar et al. (2015), }\end{array}$ \\
\hline & & Market position & $\begin{array}{l}\text { Financial strength, market share, efficiency, strategic alignment, adaptability, } \\
\text { customer relationships, customer communications }\end{array}$ & $\begin{array}{l}\text { Sheffi and Rice (2005), Boone } \text { et al. (2013), Wu } \text { et al. (2013), } \\
\text { Day (2014), Melnyk et al. (2014), Fiksel } \text { et al. (2015), Seville } \\
\text { et al. (2015) }\end{array}$ \\
\hline & \multirow{2}{*}{$\begin{array}{l}\text { Ability to } \\
\text { Learn }\end{array}$} & $\begin{array}{l}\text { Knowledge } \\
\text { management } \\
\text { (Post-disruption) }\end{array}$ & $\begin{array}{l}\text { Education and training, post-disruption feedback, cost/benefits knowledge, } \\
\text { becoming a learning organisation, looking beyond risks to see opportunities, } \\
\text { increasing innovativeness in contingency planning and continuity management }\end{array}$ & $\begin{array}{l}\text { Rice and Caniato (2003), Stecke and Kumar (2009), } \\
\text { Blackhurst et al. (2011), Golgeci and Ponomarov (2013), } \\
\text { Gölgeci and Ponomarov (2015), Seville } \text { et al. (2015) }\end{array}$ \\
\hline & & $\begin{array}{l}\text { Building social } \\
\text { capital }\end{array}$ & $\begin{array}{l}\text { Trust, inter-organisational relationships, relational competence, leverage co- } \\
\text { creation processes }\end{array}$ & $\begin{array}{l}\text { Johnson et al. (2013), Wieland and Wallenburg (2013), Day } \\
\text { (2014), Seville et al. (2015) }\end{array}$ \\
\hline
\end{tabular}




\subsubsection{Establishing Relationships and Interactions in Managerial Practices}

In the context of the pre-disruption phase, five essential proactive elements and their related practices were identified, which can gauge the level of SCRES readiness so as to anticipate the potential impact of disruption:

1. Situation awareness involves an understanding of supply chain vulnerabilities and planning for disruptions events. It requires company's ability to discern a possible disruption by sensing and interpreting events through early warning strategies and continuity planning ( Priya Datta et al., 2007;Pettit et al., 2010; Sáenz and Revilla, 2014). These practices will help in mapping supply chain vulnerabilities so as to avoid, contain or control risks (Manuj and Mentzer, 2008; Melnyk et al., 2010; Sáenz and Revilla, 2014; Stecke and Kumar, 2009). However, they require coordination, information sharing and pre-existing knowledge among supply chain partners to proactively develop and improve the level of situation awareness in anticipating disruptions (Vargo and Seville, 2011).

2. Robustness is the ability of the supply chain to resist change, and entails proactive anticipation of change before it occurs (Wieland and Wallenburg, 2012, 2013). Building robustness involves strategic decisions related to supply chain network design - designing a value-creating supply chain network structure (Tang, 2006) - , which sustains the operation during and after disruptive events (Klibi et al., 2010). A robust supply chain can function despite disturbances as it withstands and copes with shocks by retaining its stability when changes occur ( Meepetchdee and Shah, 2007; Wallace and Choi, 2011; Wieland, 2013; Durach et al., 2015b).

Supply chain robustness can be achieved by proactively configuring supply chain network density and complexity (Craighead et al., 2007), critical location (Knemeyer et al., 2009), product design (Khan et al., 2012), supply base strategies (Christopher and Peck, 2004) and segmenting the supply chain over a wide variety of possible scenarios (Chopra and Sodhi, 2014).

3. Visibility serves as a warning strategy that provides valuable time for firms to align their capabilities to minimise disruptive impact (Stecke and Kumar, 2009). It also generates awareness on the current status of supply chain operating assets and the environment by continuously monitoring the performance using KPI metrics ( Melnyk et al., 2014; Ambulkar et al., 2015; Fiksel et al., 2015). Increased visibility in supply 
chains can be enhanced by investing in IT capabilities that enable transparency through integrated information-sharing and connectivity (Melnyk et al., 2010; Brandon-Jones et al., 2014; Jüttner and Maklan, 2011;).

4. Security is an essential part of SCRES that should be designed in advance rather than sought after an incident (Rice and Caniato, 2003; Sarathy, 2006). Building security protects the supply chain against deliberate attacks such as counterfeiting, and helps to ensure cyber-security and freight security (Manuj and Mentzer, 2008; Stevenson and Busby, 2015). Moreover, security can be improved by creating synergies with supply chain partners and public-private partnerships (Bakshi and Kleindorfer, 2009; Stewart et al., 2009; Voss and Williams, 2013).

5. Knowledge management and understanding of supply chain and human resource structures are the building blocks for creating resilient supply chain (Blackhurst et al., 2011; Pettit et al., 2013; Scholten et al., 2014). Hence, SCRES is improved by cultivating knowledge management in the pre-disruption phase through practices such as education and training (Jüttner and Maklan, 2011), creating an SCRM/SCRES culture (Christopher and Peck, 2004) and supply chain drills, simulations and exercises (Rice and Caniato, 2003).

In the context of during-disruption phase, four vital concurrent elements and their practices were acknowledged that can help in assessing the level of SCRES responsiveness to adapt and respond to an event during a disruption:

1. Figure 7 shows Flexibility as the second most discussed element in the SCRES literature. This is due to the benefits that flexible supply chains acquire along all supply chain functions, strategies and customer relationships. Various authors have highlighted different ways to develop flexibility in SCM as an efficienct approach that enhance supply chain resilience. Flexibility is addressed in the context of supply and/or demand management, business process performance, order fulfillment and transportation (Tang and Tomlin, 2008; Zsidisin and Wagner, 2010; Ishfaq, 2012; Azevedo et al., 2013; Pettit et al., 2013;). Increasing flexibility provides companies the ability to adapt to changes quickly and readily in the case of disruption and to facilitate operational efficiencies in normal conditions (Sheffi and Rice, 2005). Flexible decisions help firms to adjust to rather than withstand disruptions by redeploying dedicated capacity (Rice and Caniato, 2003; Wallace and Choi, 2011). 
2. Redundancy entails maintaining excess capacity that help supply chain to respond to disruptions (Rice and Caniato, 2003). Redundancy can be achieved through creating more capital investments and strategically using the excess capacity in production (Sheffi and Rice, 2005), transportation (Stecke and Kumar, 2009), inventory (Wu et al., 2013) or storage facilities (Ratick et al., 2008).

3. Collaboration is the ability to respond to supply chain disruptions with partners through collaborative planning and information and intelligence-sharing (Christopher and Peck, 2004; Jüttner and Maklan, 2011; Pettit et al., 2013). Vertical collaboration and horizontal collaboration between supply chain partners are shown to increase SCRES (Leat and Revoredo-Giha, 2013).

4. Agility refers to the supply chain ability in responding rapidly to the disruptions and changes that hit supply chain functions. In this phase, it improves the time of SC response to the variations in risk mitigation and market response (Braunscheidel and Suresh, 2009). An agile supply chain possesses qualities such as increased velocity to quickly adapt to unexpected demand or supply changes (Christopher and Peck, 2004; Jüttner and Maklan, 2011), acceleration to speed up the reaction time (Wieland and Wallenburg, 2013) and responsiveness to react to changes (Cabral et al., 2012; Ivanov et al., 2014).

In the post-disruption phase, four crucial reactive elements and their practices were identified that can characterise and help in evaluating the level of SCRES recovery and learning in the aftermath of the event:

1. Evaluating supply chain contingency plans in the post-disruption phase enhances firm's resilient capabilities and improves its ability to recover. In particular, practices such as supply chain reconfiguration (Blackhurst et al., 2005; Craighead et al., 2007), resource reconfiguration (Ambulkar et al., 2015), resource mobilisation (Pettit et al., 2010) and scenario analysis (Colicchia et al., 2010; Melnyk et al., 2010) are essential for developing effective contengency plans. Measuring these practices will assist in improving supply chain restoration plans, especially in transportation and communications (Gong et al., 2014), and reducing time to market on new product introduction to normal operational state (Blos et al., 2010).

2. Supply Chains ability to recover from disruption events is positively related with the strength of its market position. Strong market positions provides companies strong financial situation and organisational efficiency (Ponomarov and Holcomb, 2009; 
Fiksel et al., 2015). It is associated with increased market share and results in high profit margins, which is important to add more investments in developing resilient capabilities for supply chains (Pettit et al., 2010; Sheffi and Rice, 2005). The market position also helps companies to maintain healthy customer relationships in the aftermath of disruption events (Melnyk et al., 2014).

3. The efficient management of the knowledge in the Post-disruption phase enhances supply chains ability to learn from events. Resilient supply chains cultivate their ability to learn in the aftermath of the disruptions through education and training, post-disruption feedback and cost/benefit knowledge (Rice and Caniato, 2003; Blackhurst et al., 2011;). They also look beyond risks to see opportunities and are innovative in their contingency planning and continuity management (Gölgeci and Ponomarov, 2015; Seville et al., 2015). The ability to learn after a disruption and develop better solutions for future disturbances is a fundamental element of SCRES (Ponomarov and Holcomb, 2009).

4. Building social capital among supply chain partners and across other entities such as community stakeholders strengthens the ability to learn even more. Social capital may be nurtured and emerged in the post-disruption period as a result of interorganisational relationships and relational competence (Johnson et al., 2013; Wieland and Wallenburg, 2013). Such practices can be further fostered by building trust and leveraging co-creation processes (Seville et al., 2015).

\subsection{SCRES Conceptual Clarity: Linking the Constructs in a Concept Mapping Framework}

Answering the first two sub-questions in this review has helped to provide insights into the central question: How can the concept of supply chain resilience be analysed to inform research and practice? The systematic SCRES literature review established a number of key features of a resilient supply chain, which were discussed at different levels of the constructs such as phases, strategies, capabilities, elements and their practices. As discussed in the previous section, the promise of SCRES, cannot be achieved within the supply chain by focusing on the individual concepts without understanding their interactions (Ponomarov and Holcomb, 2009; Bhamra et al., 2011). Similarly, resilience does not just happen; it is an ability that is cultivated and maintained (Seville et al., 2015) by understanding the relationships that exist. Furthermore, these complex relationships and dynamic interactions among SCRES constructs have to be linked to improve conceptual clarity. Hence, the 
premise of sub-question three: How can SCRES constructs be linked to improve conceptual clarity? That is, to synthesise the current body of knowledge to understand the potential of SCRES by identifying the relationships and interactions of the constructs.

In taking a holistic view, different constructs of SCRES are integrated to understand their relationships through a concept map. Concept maps are graphical tools used to organise and represent knowledge in a particular field, to seek answers to a focus question in a hierarchical structure (Novak and Cañas, 2008). Their value, when applied to SCRES, is in identifying key ideas so as to understand the theory, concepts and relationships between them (Rowley and Slack, 2004). Mapping the field helps to provide sufficient knowledge to develop crucial understanding, and highlights the distribution of interests in the topic (Hart, 1998). A concept map is therefore a useful tool to evaluate and synthesise the SCRES concept by representing the different components for building and improving the body of knowledge in the field.

Using the IHMC CmapTools (http://cmap.ihmc.us) computer software program, Figure 8 below shows the mapping of the SCRES concept based on the SLR. The reviewed literature supports the integration of the various constructs of SCRES, and provides an adequate theoretical basis for framing the concept and examining the relationships between the phases, strategies, capabilities, elements and their practices. Identifying these relationships is necessary so that researchers and practitioners can improve the knowledge and practice of SCRES. 
Figure 8 SCRES concept mapping framework

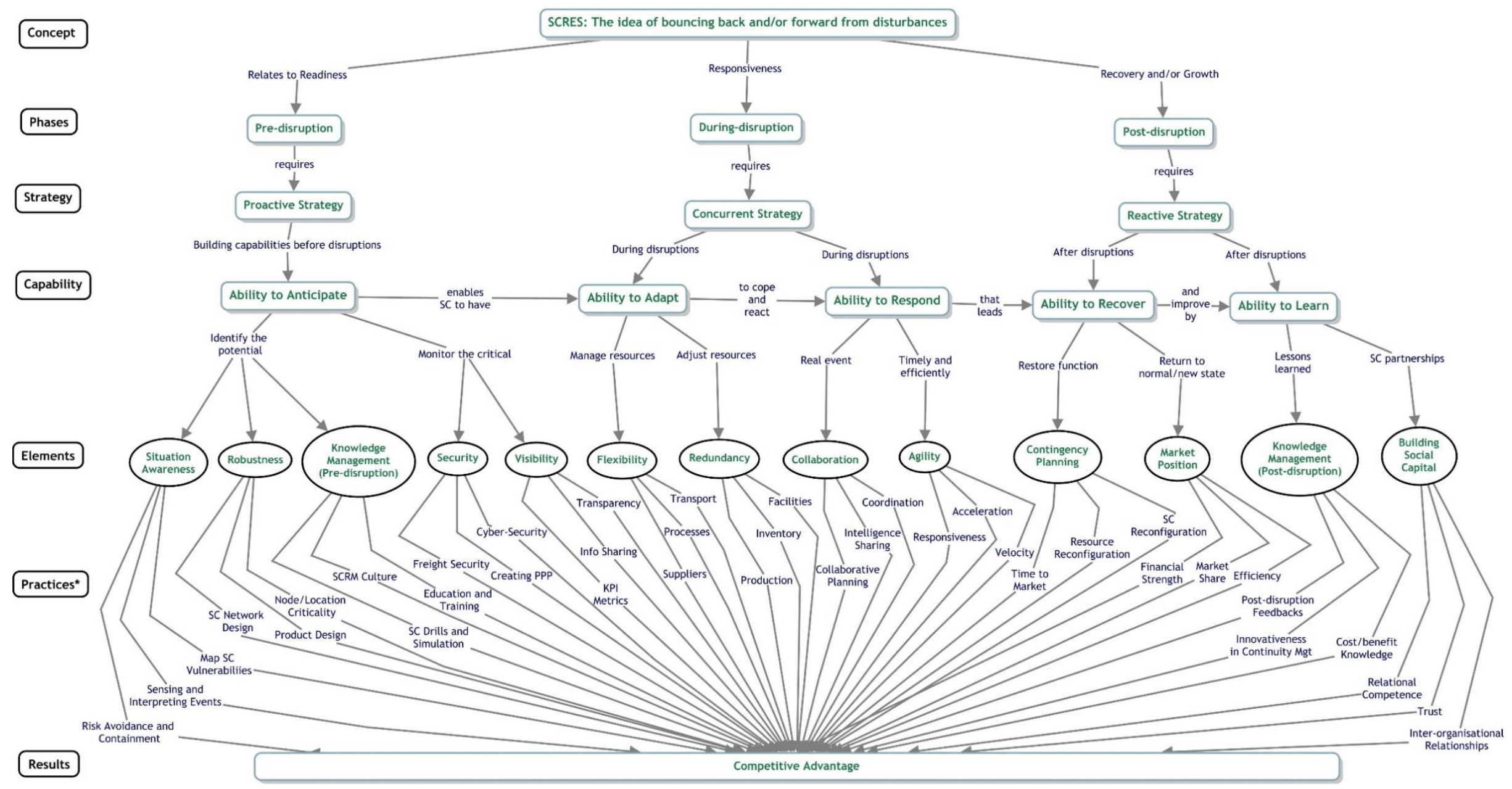

* For a full list of practices, see Table 6. 


\section{Implications for Research and Practice}

Supply chains are exposed to various disruptive events and shocks, and often operate in volatile markets (Craighead et al., 2007; Christopher and Holweg, 2011). How can they anticipate, respond, recover and grow from such disturbances (Sheffi and Rice, 2005; Pettit et $a l ., 2013)$ ? In essence, this is the central question behind the concept of SCRES. In addressing these issues, various SCRES attributes are proposed in the literature, resulting in differing ways in which the concept is defined, examined and applied in the field of SCM. To date, however, no research has integrated the various SCRES constructs into the holistic model of a concept mapping framework so as to establish connections and relationships between them. This review attempts to fill this gap by conceptualising SCRES and exploring the relationships among its related constructs, to further develop the understanding and its application. This study, therefore, has both managerial and research implications.

\subsection{Managerial Implications}

Recent events such as the floods in Thailand in 2011, earthquake and tsunami in Japan in 2011, and the massive Tianjin explosions in China in 2015 are a reminder that disruptive events are inevitable and will continue to affect supply chains. These events have affected suppliers in industries such as aerospace, electronics and automotive, to name a few, and the effects have resonated across the supply chains. Many organisations, however, suffer from a lack of guidance on effective resilience capabilities (Blackhurst et al., 2011). This study has identified five core SCRES capabilities to build a resilient supply chain. For managers, the advantages of cultivating these five capabilities are as follows.

First, the five SCRES capabilities encompass the full range of supply chain risk management (SCRM) strategies (proactive, concurrent and reactive), and thus provide a mechanism to cope with risks and changes from varied sources. For example, Sáenz and Revilla (2014) provide insights into how Cisco Systems was able to evaluate the disruption impact of the 2011 tsunami in Japan on more than 300 suppliers within 12 hours, due to the effectiveness of its proactive and reactive capabilities.

Second, supply chain disruptive events have increased over the years, and SCRES is considered as a fundamental way of coping with such disturbances (Christopher and Peck, 2004; Sheffi and Rice, 2005). The concept mapping framework provides managerial guidance on cultivating and building SCRES. The framework links SCRES phases and 
strategies, and the required capabilities, elements and practices needed to maintain competitive advantage. For example, firms can implement effective capabilities in the predisruption phase by understanding their capacity to identify and monitor a potential problem. In nurturing such behaviours, firms provide a platform for their managers not only to build their SCRES capabilities but also to leverage these capabilities to increase their competitive advantage.

Third, by refining these five capabilities, managers are in a position to assess their resilience weaknesses and strength, and the effectiveness of the elements and practices that support these capabilities. Thus, managers can use these capabilities as an evaluative tool to assess their overall resilience and thereby improve and manage their SCRES. For example, studies have shown that building flexibility is cost-efficient and generates competitive advantage in the marketplace compared to building redundancy, which is costly due to keeping resources in reserve (Sheffi and Rice, 2005; Zsidisin and Wagner, 2010). Such decisions should prompt debate among managers when developing these elements to support their SCRES capabilities.

\subsection{Research Implications}

The main research contribution of this study is the analysis of the SCRES concept through a concept mapping framework, guided by an SLR approach, in order to improve its conceptual clarity. The evaluation and synthesis of the current body of knowledge have enhanced the understanding of SCRES and have several implications in terms of developing the current literature.

First, the SLR synthesis found three constructs used to define SCRES; namely, phases, strategies and capabilities. This finding supports the argument that SCRES is an abstract concept and its utility in the SCM domain still lacks clarity. Tighter construct definitions are needed to enhance the usefulness of the concept. Second, the concept mapping approach provides a foundation for future empirical studies of SCRES to analyse the relationships between SCRES constructs and address the current gap in the literature. This review presented an opportunity to operationalise SCRES constructs and to test the interactions and relationships between them. Third, the elements and practices identified to support SCRES capabilities can be used to understand their application and value in different industry perspectives. Although previous studies have empirically analysed elements such as collaboration (Scholten and Schilder, 2015), visibility (Brandon-Jones et al., 2014) and flexibility (Zsidisin and Wagner, 2010), more studies are needed, to examine the value of 
these elements in practice. This study provides a source for exploring the applicability and effectiveness of the elements and their practices in different industry settings.

\section{Limitations and Recommendations for Further Research}

Despite the scientific approach of SLR, and the findings and implications highlighted in the previous section, this study has certain limitations. First, it is exploratory and based on the relevant literature over the past 13 years that is available in six databases. Second, the articles selected in the review process were limited to peer-reviewed journal articles, and thus the review was not exhaustive. Although peer-review journals are considered to be of higher quality, other sources such as conference papers, books and trade journals are also vital sources of knowledge on this topic. Third, the focus of this study was to analysis the concept of SCRES from a holistic perspective, rather than a particular function in SCM.

Despite these limitations, the value of this study lies in the accumulation of findings and the synthesis of the body of knowledge on SCRES "that is not apparent from reading the individual studies in isolation" (Denyer and Tranfield, 2009, p. 685). Consequently, the findings from the SCRES concept analysis have highlighted several paths for further research to advance this topic.

First, the concept mapping framework provides insights into the relationship and dynamic interplay of different SCRES constructs. This study, however, due to its exploratory nature, did not address any moderating, mediating or contingent factors (e.g. trust, uncertainty, complexity) for these attributes. Further research is encouraged to investigate the supporting role of such factors in building SCRES; specifically, the interactions that affect resilience behaviour and performance. Such studies will complement and build upon previous work concerning supply chain disruptions (e.g. Bode et al., 2011).

Second, despite the blossoming literature on the topic, there is a need to apply wellestablished theoretical lenses to ground the usefulness of the concept in the SCM domain - in particular, theories that consider the dynamic and non-linear relationships of supply chain functions. Indeed, previous studies have suggested theories that can address the complexities of the SCRES phenomenon - for example, complex adaptive systems (e.g. Day, 2014; Tukamuhabwa et al., 2015), contingency theory (e.g. Brandon-Jones et al., 2014), social capital (e.g. Johnson et al., 2013) and strategic choice (e.g. Pereira et al., 2014). Also, the applicability of theories such as high-reliability organisations (La Porte, 1996) and normal 
accident theory (Perrow, 1999) that address organisational safety should be considered to test their usefulness in SCRES studies.

Third, the review findings reveal that less empirical research exists compared to nonempirical studies (see Figure 2). While this can be attributed to the infancy of the topic in the SCM domain (Blackhurst et al., 2011), more rigorous empirical research is needed to test the potential and ascertain the value of SCRES. Consistent with other researchers, it is suggested that rigorous methodologies such as longitudinal studies are needed to identify the progress of SCRES strategies over time (e.g. Blackhurst et al., 2011; Jüttner and Maklan, 2011). Also, it is recommended to use mixed-methods studies for robust analysis to capture both in-depth views and a broader understanding of SCRES practices (e.g. Pettit et al., 2013; Pereira et al., 2014).

Fourth, the next logical step in the development of the topic is to operationalise SCRES capabilities in order to assess its merits. Although previous research has attempted to measure SCRES capabilities (e.g. Azevedo et al., 2013; Pettit et al., 2013), only a few studies have focused on the multi-dimensional nature of SCRES (e.g. Vugrin et al., 2011). As shown in the concept mapping framework (Figure 8), the interactions of the constructs are crucial; any proposed metrics should take a holistic view of SCRES by extending its application in practice beyond the boundaries of a single firm (Ambulkar et al., 2015). Such measures pose challenges for organisations with complex global supply chains; nevertheless, identifying suitable indicators and metrics of SCRES capabilities would represent a significant advance in research and practice.

Finally, the idea of 'bouncing back' from adversity while sustaining operations and thriving in the process is promising; however, building SCRES capabilities is not cheap. Trade-off decisions between SCRES investment and cost need to be further investigated (Jüttner and Maklan, 2011; Pereira et al., 2014). These decisions can involve the question of when to invest in spare capacities to reduce vulnerabilities, and where to minimise such investments to cultivate adaptive capabilities. A balance between capability and vulnerability is desirable to achieve balanced resilience (Pettit et al., 2013). A future research to further investigate the five SCRES capabilities and the trade-offs between them is suggested. 


\section{Conclusion}

The concept of SCRES offers a way for supply chains to harness capabilities that enable them to bounce back and/or forward from adversity to achieve business continuity. Likewise, building SCRES is seen as an essential strategic capability to improve a firm's competitiveness by turning disruptive events, and changes in the market and the environment into opportunities (Sheffi and Rice, 2005; Seville et al., 2015). However, when one examines the literature underpinning the review question "How can the concept of supply chain resilience be analysed to inform research and practice?" inconsistencies emerge surrounding the various aspects of the idea, suggesting that further theoretical explanations on the topic are warranted. The exploratory approach and development of a holistic model have allowed us to integrate fragments from the current body of knowledge. This study synthesised the results of analysing 103 peer-reviewed academic articles to address the central question via three sub-questions.

The first sub-question was: What are the constructs used to define SCRES? Three constructs emerged from the evaluation of the various definitions. The first construct relates to the three phases of resilience that cover the moments of pre-disruption, during-disruption, and postdisruption. The second refers to the three strategies used to prepare for, respond to and recover from disruptions: proactive, concurrent and reactive. The third relates to the capabilities needed for supply chains to be resilient. One of the significant findings to emerge from the reviewed definitions is the common terms and themes implied to describe these capabilities, despite the diversity of definitions. The five core SCRES capabilities identified are the ability to anticipate, adapt, respond, recover and learn.

The second sub-question was: What are the essential elements and managerial practices needed to support SCRES capabilities? This study has revealed the array of expressions used to describe this feature, and this is a source of inconsistencies in the SCRES literature. To maintain consistency and align with other researchers (e.g. Christopher and Peck, 2004; Hohenstein et al., 2015), these were referred to as elements. The reviewed literature revealed 27 elements, but the need to consolidate them in order to improve clarity and relevance is needed. Based on this premise, 13 essential elements and related practices were identified to support the five SCRES capabilities. 
Finally, the third sub-question was: How can SCRES constructs be linked to improve conceptual clarity? In an attempt to consolidate and link the features of SCRES to improve clarity, this study provides a holistic model of SCRES through a concept mapping approach. The concept mapping classifies the different features of SCRES and establishes the complex relationships and dynamic interactions between them. The study therefore has both theoretical and practical implications. It contributes to increasing managerial awareness of the links between the constructs, thus enabling better practices. It also lays the foundation for future research to investigate the underlying theory and practice involved, and hence promote the creation of resilient supply chains.

\section{References}

*Abe, S. (2014), "Impact of the great Thai floods on the international supply chain", Malaysian Journal of Economic Studies, Vol. 51, pp. 147-155.

*Aigbogun, O., Ghazali, Z. and Razali, R. (2014), “A Framework to Enhance Supply Chain Resilience The Case of Malaysian Pharmaceutical Industry", Global Business and Management Research: An International Journal, Vol. 6 No. 3, pp. 219-228.

Ambulkar, S., Blackhurst, J. and Grawe, S. (2015), "Firm's resilience to supply chain disruptions: Scale development and empirical examination", Journal of Operations Management, Elsevier B.V., Vol. 33-34, pp. 111-122.

Azadeh, A., Atrchin, N., Salehi, V. and Shojaei, H. (2014), "Modelling and improvement of supply chain with imprecise transportation delays and resilience factors", International Journal of Logistics Research and Applications, Vol. 17 No. 4, pp. 269-282.

Azevedo, S.G., Govindan, K., Carvalho, H. and Cruz-Machado, V. (2013), "Ecosilient Index to assess the greenness and resilience of the upstream automotive supply chain", Journal of Cleaner Production, Vol. 56, pp. 131-146.

Bakshi, N. and Kleindorfer, P. (2009), "Co-opetition and Investment for Supply-Chain Resilience”, Production and Operations Management, Vol. 18 No. 6, pp. 583-603.

Berle, Ø., Norstad, I. and Asbjørnslett, B.E. (2013), "Optimization, risk assessment and resilience in LNG transportation systems", Supply Chain Management: An International Journal, Vol. 18 No. 3, pp. 253264.

Bhamra, R., Dani, S. and Burnard, K. (2011), "Resilience: the concept, a literature review and future directions", International Journal of Production Research, Vol. 49 No. 18, pp. 5375-5393.

Bhattacharya, A., Geraghty, J., Young, P. and Byrne, P.J. (2013), "Design of a resilient shock absorber for disrupted supply chain networks: a shock-dampening fortification framework for mitigating excursion events", Production Planning \& Control: The Management of Operations, Vol. 24 No. 8-9, pp. 721-742.

Blackhurst, J., Craighead, C.W., Elkins, D. and Handfield, R.B. (2005), "An empirically derived agenda of critical research issues for managing supply-chain disruptions", International Journal of Production Research, Vol. 43 No. 19, pp. 4067-4081.

Blackhurst, J., Dunn, K.S. and Craighead, C.W. (2011), “An Empirically Derived Framework of Global Supply Resiliency”, Journal of Business Logistics, Vol. 32 No. 4, pp. 374-391.

Blos, M.F., Wee, H.-M. and Yang, J. (2010), "Analysing the external supply chain risk driver competitiveness: a risk mitigation framework and business continuity plan.", Journal of Business Continuity \& Emergency Planning, Vol. 4 No. 4, pp. 368-74.

Bode, C., Wagner, M.S., Petersen, J.K. and Ellram, M.L. (2011), "Understanding Responses to Supply Chain Disruptions : Insights from Information Processing and Resource Dependence Perspectives", Academy of Management Journal, Vol. 54 No. 4, pp. 833-856.

Boone, C.A., Craighead, C.W., Hanna, J.B. and Nair, A. (2013), "Implementation of a system approach for enhanced supply chain continuity and resiliency: A longitudinal study", Journal of Business Logistics, Council of Supply Chain Management Professionals, Vol. 34 No. 3, pp. 222-235.

Booth, A., Papaioannou, D. and Sutton, A. (2012), Systematic Approaches to a Successful Literature Review, SAGE Publications, Thousand Oaks, California. 
Boyes, H., Toffler, A. and Boyes, H. (2015), “Cybersecurity and Cyber-Resilient Supply Chains”, Technology Innovation Management Review, Vol. 5 No. 4, pp. 28-34.

Brandon-Jones, E., Squire, B., Autry, C.W. and Petersen, K.J. (2014), “A Contingent Resource-Based Perspective of Supply Chain Resilience and Robustness", Journal of Supply Chain Management, Vol. 50 No. 3, pp. 55-73.

Braunscheidel, M.J. and Suresh, N.C. (2009), "The organizational antecedents of a firm's supply chain agility for risk mitigation and response", Journal of Operations Management, Vol. 27 No. 2, pp. 119-140.

Briner, B.R. and Denyer, D. (2012), "Systematic review and evidence synthesis as a practice and scholarship tool", in Rousseau, M.D. (Ed.), The Oxford Handbook of Evidence-Based Management, Oxford University Press, Oxford, pp. 112-129.

de Bruijne, M., Boin, A. and van Eeten, M. (2010), "Resilience: Exploring the Concepts and its Meaning", in Comfort, K.L., Boin, A. and Demchak, C.C. (Eds.), Designing Resilience : Preparing for Extreme Events, University of Pittsburgh Press, Pittsburgh, Pa., pp. 13-32.

Cabral, I., Grilo, A. and Cruz-Machado, V. (2012), "A decision-making model for Lean, Agile, Resilient and Green supply chain management”, International Journal of Production Research, Vol. 50 No. 17, pp. 4830-4845.

Carvalho, H., Azevedo, S.G. and Machado, V.C. (2014), "Supply chain management resilience: a theory building approach", International Journal of Supply Chain and Operations Resilience, Vol. 1 No. 1, pp. $3-27$.

Carvalho, H., Barroso, P.A., Machado, H.V., Azevedo, S. and Cruz-Machado, V. (2012), "Supply chain redesign for resilience using simulation”, Computers \& Industrial Engineering, Vol. 62 No. 1, pp. 329341.

Carvalho, H., Duarte, S. and Machado, V.C. (2011), "Lean, agile, resilient and green: divergencies and synergies", International Journal of Lean Six Sigma, Vol. 2 No. 2, pp. 151-179.

Chopra, S. and Sodhi, M.S. (2014), "Reducing the risk of supply chain disruptions", MIT Sloan Management Review, Massachusetts Institute of Technology, Vol. 55 No. 3, pp. 73-80.

Christopher, M. (2000), "The Agile Supply Chain: Competing in Volatile Markets", Industrial Marketing Management, Vol. 29 No. 1, pp. 37-44.

Christopher, M. and Holweg, M. (2011), "Supply Chain 2.0': managing supply chains in the era of turbulence", International Journal of Physical Distribution \& Logistics Management, Vol. 41 No. 1, pp. 63-82.

Christopher, M., Mena, C., Khan, O. and Yurt, O. (2011), “Approaches to managing global sourcing risk", Supply Chain Management: An International Journal, Vol. 16 No. 2, pp. 67-81.

Christopher, M. and Peck, H. (2004), "Building the Resilient Supply Chain", The International Journal of Logistics Management, Vol. 15 No. 2, pp. 1-13.

Colicchia, C., Dallari, F. and Melacini, M. (2010), "Increasing supply chain resilience in a global sourcing context", Production Planning \& Control, Vol. 21 No. 7, pp. 680-694.

Craighead, C.W., Blackhurst, J., Rungtusanatham, M.J. and Handfield, R.B. (2007), "The severity of supply chain disruptions: Design characteristics and mitigation capabilities", Decision Sciences, Vol. 38 No. 1, pp. 131-156.

Cranfield University: School of Management. (2002), Supply Chain Vulnerability Executive Report On Behalf of: Department for Transport, Local Government and the Regions, available at:http://doi.org/10.1108/eb016623.

Cranfield University: School of Management. (2003), "Creating Resilient Supply Chains: A Practical Guide"”, Report Produced by the Centre for Logistics and Supply Chain Management, Cranfield School of Management.

Davis, A. (2015), "Building Cyber-Resilience into Supply Chains", Technology Innovation Management Review, Vol. 5 No. 4, pp. 19-27.

Day, J.M. (2014), "Fostering emergent resilience: the complex adaptive supply network of disaster relief", International Journal of Production Research, Vol. 52 No. 7, pp. 1970-1988.

Denyer, D. and Tranfield, D. (2009), "Producing a systematic review.", in Buchanan, A.D. and Bryman, A. (Eds.), The Sage Handbook of Organizational Research Methods, Sage Publications Ltd, London, pp. 671-689.

Dowty, R.A. and Wallace, W.A. (2010), "Implications of organizational culture for supply chain disruption and restoration", International Journal of Production Economics, Vol. 126 No. 1, pp. 57-65.

Durach, C.F., Wieland, A. and Machuca, J.A.D. (2015a), "Antecedents and dimensions of supply chain robustness: a systematic literature review", International Journal of Physical Distribution \& Logistics Management, Vol. 45 No. 1/2, pp. 118-137.

Durach, F.C., Wieland, A. and Machuca, A.D.J. (2015b), "Antecedents and dimensions of supply chain robustness: a systematic literature review", International Journal of Physical Distribution \& Logistics Management, Vol. 45 No. 1/2, pp. 118-137. 
Fiksel, J., Croxton, K.L. and Pettit, T.J. (2015), "From Risk to Resilience: Learning to Deal With Disruption”, MIT Sloan Management Review, Vol. 56 No. 2, pp. 78-86.

Glendon, L. (2013), "Winners and losers in the complex web", Journal of Business Continuity \& Emergency Planning, Vol. 6 No. 4, pp. 322-328.

Gölgeci, I. and Ponomarov, S.Y. (2015), "How does firm innovativeness enable supply chain resilience? The moderating role of supply uncertainty and interdependence", Technology Analysis \& Strategic Management, Vol. 27 No. 3, pp. 267-282.

Golgeci, I. and Ponomarov, Y.S. (2013), "Does firm innovativeness enable effective responses to supply chain disruptions? An empirical study", Supply Chain Management: An International Journal, Vol. 18 No. 6 , pp. 604-617.

Gong, J., Mitchell, E.J., Krishnamurthy, A. and Wallace, A.W. (2014), “An interdependent layered network model for a resilient supply chain”, Omega, Vol. 46, pp. 104-116.

Harrison, T.P., Houm, P.J., Thomas, D.J. and Craighead, C.W. (2013), "Supply chain disruptions are inevitableget READI: Resiliency enhancement analysis via deletion and insertion”, Transportation Journal, Vol. 52 No. 2, pp. 264-276.

Hart, C. (1998), Doing a Literature Review: Releasing the Social Science Research Imagination, SAGE Publications, London.

Hearnshaw, J.S.E. and Wilson, M.J.M. (2013), "A complex network approach to supply chain network theory", International Journal of Operations \& Production Management, Vol. 33 No. 4, pp. 442-469.

Heckmann, I., Comes, T. and Nickel, S. (2015), “A critical review on supply chain risk - Definition, measure and modeling”, Omega, Vol. 52, pp. 119-132.

Higgins, A., Miller, C., Archer, A., Ton, T., Fletcher, C. and McAllister, R. (2010), "Challenges of operations research practice in agricultural value chains", Journal of the Operational Research Society, Vol. 61 No. 6, pp. 964-973.

Hohenstein, N.-O., Feisel, E. and Hartmann, E. (2015), "Research on the phenomenon of supply chain resilience: A systematic review and paths for further investigation", International Journal of Physical Distribution \& Logistics Management, Vol. 45 No. 1/2, pp. 90-117.

Holling, C.S. (1973), "Resilience and Stability of Ecological Systems", Annual Review of Ecology and Systematics, Vol. 4, pp. 1-23.

Hollnagel, E. (2011), "Epilogue: RAG - The Resilience Analysis Grid”, in Hollnagel, E., Paries, J., Woods, D. and Wreathall, J. (Eds.), Resilience Engineering in Practice: A Guidebook, Ashgate Press, Surrey, pp. 275-296.

Hollnagel, E., Woods, D.D. and Leveson, N. (2006), Resilience Engineering: Concepts and Precepts, edited by Hollnagel, E., Woods, D.D. and Leveson, N., Ashgate Publishing Limited, Aldershot, Hampshire.

Ishfaq, R. (2012), "Resilience through flexibility in transportation operations", International Journal of Logistics Research and Applications, Vol. 15 No. 4, pp. 215-229.

Ismail, H.S., Poolton, J. and Sharifi, H. (2011), "The role of agile strategic capabilities in achieving resilience in manufacturing-based small companies”, International Journal of Production Research, Vol. 49 No. 18, pp. 5469-5487.

Ivanov, D., Sokolov, B. and Dolgui, A. (2014), "The Ripple effect in supply chains: trade-off 'efficiencyflexibility-resilience' in disruption management”, International Journal of Production Research, Vol. 52 No. 7, pp. 2154-2172.

Johnson, N., Elliott, D. and Drake, P. (2013), "Exploring the role of social capital in facilitating supply chain resilience", Supply Chain Management: An International Journal, Vol. 18 No. 3, pp. 324-336.

Jüttner, U. and Maklan, S. (2011), "Supply chain resilience in the global financial crisis: an empirical study", Supply Chain Management: An International Journal, Vol. 16 No. 4, pp. 246-259.

Khan, O., Christopher, M. and Creazza, A. (2012), "Aligning product design with the supply chain: a case study”, Supply Chain Management: An International Journal, Vol. 17 No. 3, pp. 323-336.

Klibi, W., Martel, A. and Guitouni, A. (2010), "The design of robust value-creating supply chain networks: A critical review", European Journal of Operational Research, Vol. 203 No. 2, pp. 283-293.

Knemeyer, a. M., Zinn, W. and Eroglu, C. (2009), "Proactive planning for catastrophic events in supply chains", Journal of Operations Management, Vol. 27 No. 2, pp. 141-153.

Kristianto, Y., Gunasekaran, A., Helo, P. and Hao, Y. (2014), "A model of resilient supply chain network design: A two-stage programming with fuzzy shortest path", Expert Systems with Applications, Vol. 41 No. 1, pp. 39-49.

Kumar, S. and Sosnoski, M. (2011), "Decision framework for the analysis and selection of appropriate transfer pricing for a resilient global SME manufacturing operation - a business case", International Journal of Production Research, Vol. 49 No. 18, pp. 5431-5448.

Kumar, S.K., Tiwari, M.K. and Babiceanu, R.F. (2010), "Minimisation of supply chain cost with embedded risk using computational intelligence approaches”, International Journal of Production Research, Vol. 48 No. 
13, pp. 3717-3739.

Leat, P. and Revoredo-Giha, C. (2013), "Risk and resilience in agri-food supply chains: the case of the ASDA PorkLink supply chain in Scotland”, Supply Chain Management: An International Journal, Vol. 18 No. 2 , pp. 219-231.

Levesque, P. (2012), "Building resilience and sustainability into the Chinese supply chain", Global Business and Organizational Excellence, Vol. 31 No. 3, pp. 69-83.

Luthar, S.S., Cicchetti, D. and Becker, B. (2000), "The Construct of Resilience: A Critical Evaluation and Guidelines for Future Work", Child Development, Vol. 71 No. 3, pp. 543-562.

Mandal, S. (2012), “An Empirical Investigation into Supply Chain Resilience”, IUP Journal of Supply Chain Management, Vol. 9 No. 4, pp. 46-62.

Mandal, S. (2014), "Supply chain resilience: a state-of-the-art review and research directions", International Journal of Disaster Resilience in the Built Environment, Vol. 5 No. 4, pp. 427-453.

Manuj, I. and Mentzer, J.T. (2008), Global Supply Chain Risk Management Strategies, International Journal of Physical Distribution \& Logistics Management, Vol. 38.

Manyena, S.B. (2006), “The concept of resilience revisited.”, Disasters, Vol. 30 No. 4, pp. 433-50.

Mari, S.I., Lee, Y.H., Memon, M.S., Park, Y.S. and Kim, M. (2015), “Adaptivity of Complex Network Topologies for Designing Resilient Supply Chain Networks", International Journal of Industrial Engineering, Vol. 22 No. 1, pp. 102-116.

Matsuo, H. (2015), "Implications of the Tohoku earthquake for Toyota's coordination mechanism: Supply chain disruption of automotive semiconductors", International Journal of Production Economics, Vol. 161, pp. 217-227.

Meepetchdee, Y. and Shah, N. (2007), "Logistical network design with robustness and complexity considerations", International Journal of Physical Distribution \& Logistics Management, Vol. 37 No. 3 , pp. 201-222.

Melnyk, A.S., Davis, W.E., Spekman, E.R. and Sandor, J. (2010), “Outcome-Driven Supply Chains", MIT Sloan Management Review, Vol. 51 No. 2, pp. 32-38.

Melnyk, B.S.A., Closs, D.J., Griffis, S.E., Zobel, C.W. and Macdonald, J.R. (2014), “Understanding Supply Chain Resilience", Supply Chain Management Review, Vol. 18 No. 1, pp. 34-41.

Miles, B.M. and Huberman, A.M. (1994), Qualitative Data Analysis: An Expanded Sourcebook, Qualitative Data Analysis: An Expanded Sourcebook, 2nd ed., SAGE Publications, Thousand Oaks, California, available at:http://doi.org/10.1016/0149-7189(96)88232-2.

MIT Center for Transportation and Logistics. (2003), “Supply Chain Response to Terrorism: Creating Resilient and Secure Supply Chains", Interim Report of Progress and Learnings, August 8, 2003.

Moher, D., Liberati, A., Tetzlaff, J. and Altman, D.G. (2009), "Preferred Reporting Items for Systematic Reviews and Meta-Analyses: The PRISMA Statement", Annals of Internal Medicine, Vol. 151 No. 4, pp. 264-269.

Novak, D.J. and Cañas, J.A. (2008), "The Theory Underlying Concept Maps and How to Construct and Use Them”, "Technical Report IHMC CmapTools 2006-01 Rev 01-2008, Florida Institute for Human and Machine Cognition, 2008”, available at:http://doi.org/Technical Report IHMC CmapTools 2006-01 Rev 2008-01.

Peck, H. (2005), "Drivers of supply chain vulnerability: an integrated framework", International Journal of Physical Distribution \& Logistics Management, Vol. 35 No. 4, pp. 210-232.

Peck, H. (2006), "Reconciling supply chain vulnerability, risk and supply chain management", International Journal of Logistics: Research and Applications, Vol. 9 No. 2, pp. 127-142.

Pereira, J.V. (2009), “The new supply chain's frontier: Information management", International Journal of Information Management, Vol. 29 No. 5, pp. 372-379.

Pereira, R.C., Christopher, M. and Da Silva, L.A. (2014), "Achieving supply chain resilience: the role of procurement”, Supply Chain Management: An International Journal, Vol. 19 No. 5/6, pp. 626-642.

Perrow, C. (1999), Normal Accidents: Living With High-Risk Technologies, Princeton University Press, Princeton, New Jersey.

Pettit, T.J., Croxton, K.L. and Fiksel, J. (2013), "Ensuring Supply Chain Resilience: Development and Implementation of an Assessment Tool”, Journal of Business Logistics, Vol. 34 No. 1, pp. 46-76.

Pettit, T.J., Fiksel, J. and Croxton, K.L. (2010), "Ensuring Supply Chain Resilience: Development of a Conceptual Framework", Journal of Business Logistics, Vol. 31 No. 1, pp. 1-22.

Ponis, T.S. and Koronis, E. (2012), "Supply Chain Resilience: Definition of Concept and its Formative Elements", The Journal of Applied Business Research, Vol. 28 No. 5, pp. 921-930.

Ponomarov, Y.S. and Holcomb, C.M. (2009), "Understanding the concept of supply chain resilience", The International Journal of Logistics Management, Vol. 20 No. 1, pp. 124-143.

La Porte, R.T. (1996), "High Reliability Organizations: Unlikely, Demanding and At Risk", Journal of Contingencies and Crisis Management, Vol. 4 No. 2, pp. 60-71. 
Priya Datta, P., Christopher, M. and Allen, P. (2007), "Agent-based modelling of complex production/distribution systems to improve resilience", International Journal of Logistics Research and Applications, JOUR, Taylor \& Francis, Vol. 10 No. 3, pp. 187-203.

Ratick, S., Meacham, B. and Aoyama, Y. (2008), "Locating backup facilities to enhance supply chain disaster resilience", Growth and Change, Vol. 39 No. 4, pp. 642-666.

Rice, B.J. and Caniato, F. (2003), "Building a Secure and Resilient Supply Network", Supply Chain Management Review, Vol. 7 No. 5, pp. 22-30.

Rousseau, D.M., Manning, J. and Denyer, D. (2008), "Evidence in Management and Organizational Science: Assembling the Field's Full Weight of Scientific Knowledge Through Syntheses", The Academy of Management Annals, Vol. 2 No. 1, pp. 475-515.

Rowley, J. and Slack, F. (2004), "Conducting a literature review", Management Research News, JOUR, Emerald Group Publishing Limited, Vol. 27 No. 6, pp. 31-39.

Sáenz, J.M. and Revilla, E. (2014), “Creating More Resilient Supply Chains”, MIT Sloan Management Review, Vol. 55 No. 4, pp. 22-24.

Sarathy, R. (2006), "Security and the Global Supply Chain", Transportation Journal (Penn State University Press), Vol. 45 No. 4, pp. 28-51.

Sawik, T. (2013), "Selection of resilient supply portfolio under disruption risks", Omega, Vol. 41 No. 2, pp. 259-269.

Schmitt, A.J. and Singh, M. (2012), “A quantitative analysis of disruption risk in a multi-echelon supply chain”, International Journal of Production Economics, Vol. 139 No. 1, pp. 22-32.

Scholten, K. and Schilder, S. (2015), "The role of collaboration in supply chain resilience", Supply Chain Management: An International Journal, Vol. 20 No. 4, pp. 471-484.

Scholten, K., Scott, S.P. and Fynes, B. (2014), "Mitigation processes - antecedents for building supply chain resilience", Supply Chain Management: An International Journal, Vol. 19 No. 2, pp. 211-228.

Seville, E., Opstal, V.D. and Vargo, J. (2015), “A Primer in Resiliency: Seven Principles for Managing the Unexpected”, Global Business and Organizational Excellence, Vol. 34 No. 3, pp. 6-18.

Sheffi, Y. (2001), "Supply Chain Management under the Threat of International Terrorism", The International Journal of Logistics Management, Vol. 12 No. 2, pp. 1-11.

Sheffi, Y. (2007), The Resilient Enterprise: Overcoming Vulnerability for Competitive Advantage, Paperback., MIT Press, Cambridge, Massachusetts.

Sheffi, Y. (2015), The Power of Resilience: How The Best Companies Manage The Unexpected, MIT Press, Cambridge, Massachusetts.

Sheffi, Y. and Rice, B.J. (2005), "A Supply Chain View of the Resilient Enterprise", MIT Sloan Management Review, Vol. 47 No. 1, pp. 41-48.

Soni, U., Jain, V. and Kumar, S. (2014), "Measuring supply chain resilience using a deterministic modeling approach", Computers \& Industrial Engineering, Vol. 74, pp. 11-25.

Spiegler, L.M.V., Naim, M.M. and and Wikner, J. (2012), "A control engineering approach to the assessment of supply chain resilience”, International Journal of Production Research, Vol. 50 No. 21, pp. 6162-6187.

Sprecher, B., Daigo, I., Murakami, S., Kleijn, R., Vos, M. and Kramer, G.J. (2015), "Framework for Resilience in Material Supply Chains, With a Case Study from the 2010 Rare Earth Crisis", Environmental Science \& Technology, Vol. 49, pp. 6740-6750.

Starr, R., Newfrock, J. and Delurey, M. (2003), "Enterprise Resilience: Managing Risk in the Networked Economy", Strategy+Business, Vol. Spring No. 30, pp. 1-10.

Stecke, E.K. and Kumar, S. (2009), "Sources of Supply Chain Disruptions, Factors That Breed Vulnerability, and Mitigating Strategies", Journal of Marketing Channels, Vol. 16 No. 3, pp. 193-226.

Stevenson, M. and Busby, J. (2015), “An exploratory analysis of counterfeiting strategies Towards counterfeitresilient supply chains”, International Journal of Operations \& Production Management, Vol. 35 No. 1, pp. 110-144.

Stewart, G.T., Kolluru, R. and Smith, M. (2009), "Leveraging public-private partnerships to improve community resilience in times of disaster", International Journal of Physical Distribution \& Logistics Management, Vol. 39 No. 5, pp. 343-364.

Svensson, G. (2000), “A conceptual framework for the analysis of vulnerability in supply chains", International Journal of Physical Distribution \& Logistics Management, Vol. 30 No. 9, pp. 731-749.

Tang, C. (2006), "Robust strategies for mitigating supply chain disruptions", International Journal of Logistics: Research and Applications, Vol. 9 No. 1, pp. 33-45.

Tang, C. and Tomlin, B. (2008), "The power of flexibility for mitigating supply chain risks", International Journal of Production Economics, Vol. 116, pp. 12-27.

Thomas, A., Pham, D.T., Francis, M. and Fisher, R. (2015), "Creating resilient and sustainable manufacturing businesses - a conceptual fitness model”, International Journal of Production Research, Vol. 53 No. 13, pp. 3934-3946. 
Todo, Y., Nakajima, K. and Matous, P. (2015), "How do supply chain networks affect the resilience of firms to natural disasters? Evidence from the great East Japan earthquake*", Journal of Regional Science, Vol. 55 No. 2, pp. 209-229.

Tranfield, D., Denyer, D. and Smart, P. (2003), "Towards a methodology for developing evidence-informed management knowledge by means of systematic review *”, British Journal of Management, Vol. 14, pp. 207-222.

Tukamuhabwa, B.R., Stevenson, M., Busby, J. and Zorzini, M. (2015), "Supply chain resilience: definition, review and theoretical foundations for further study", International Journal of Production Research, Vol. 53 No. 18 , pp. 5592-5623.

Urciuoli, L. (2015), “Cyber-Resilience: A Strategic Approach for Supply Chain Management", Technology Innovation Management Review, Vol. 5 No. 4, pp. 13-18.

Urciuoli, L., Mohanty, S., Hintsa, J. and Gerine Boekesteijn, E. (2014), “The resilience of energy supply chains: a multiple case study approach on oil and gas supply chains to Europe", Supply Chain Management: An International Journal, Vol. 19 No. 1, pp. 46-63.

VanVactor, J.D. (2011), "Cognizant healthcare logistics management: ensuring resilience during crisis", International Journal of Disaster Resilience in the Built Environment, Vol. 2 No. 3, pp. 245-255.

Vargo, J. and Seville, E. (2011), "Crisis strategic planning for SMEs: finding the silver lining", International Journal of Production Research, Vol. 49 No. 18, pp. 5619-5635.

Voss, M.D. and Williams, Z. (2013), "Public-Private Partnerships and Supply Chain Security: C-TPAT as an Indicator of Relational Security", Journal of Business Logistics, Vol. 34 No. 4, pp. 320-334.

Vugrin, D.E., Warren, E.D. and Ehlen, A.M. (2011), “A Resilience Assessment Framework for Infrastructure and Economic Systems: Quantitative and Qualitative Resilience Analysis of Petrochemical Supply Chains to a Hurricane", Process Safety Progress, Vol. 30 No. 3, pp. 280-290.

Walker, B. and Salt, D. (2012), Resilience Practice: Building Capacity to Absorb Disturbance and Maintain Function, Island Press, Washington.

Wallace, S.W. and Choi, T.-M. (2011), "Flexibility, information structure, options, and market power in robust supply chains", International Journal of Production Economics, Vol. 134 No. 2, pp. 284-288.

Wieland, A. (2013), "Selecting the right supply chain based on risks", Journal of Manufacturing Technology Management, Vol. 24 No. 5, pp. 652-668.

Wieland, A. and Wallenburg, M.C. (2012), "Dealing with supply chain risks: Linking risk management practices and strategies to performance", International Journal of Physical Distribution \& Logistics Management, Vol. 42 No. 10, pp. 887-905.

Wieland, A. and Wallenburg, M.C. (2013), "The influence of relational competencies on supply chain resilience: a relational view", International Journal of Physical Distribution \& Logistics Management, Vol. 43 No. 4, pp. 300-320.

Williams, Z., Ponder, N. and Autry, C.W. (2009), "Supply chain security culture: measure development and validation", The International Journal of Logistics Management, Vol. 20 No. 2, pp. 243-260.

Wu, T., Huang, S., Blackhurst, J., Zhang, X. and Wang, S. (2013), "Supply Chain Risk Management: An AgentBased Simulation to Study the Impact of Retail Stockouts", IEEE Transactions on Engineering Management, Vol. 60 No. 4, pp. 676-686.

Yang, B. and Yang, Y. (2010), "Postponement in supply chain risk management: a complexity perspective", International Journal of Production Research, Vol. 48 No. 7, pp. 1901-1912.

Yang, Y. and $\mathrm{Xu}, \mathrm{X}$. (2015), "Post-disaster grain supply chain resilience with government aid", Transportation Research Part E, Vol. 76, pp. 139-159.

Zsidisin, G. a. and Wagner, S.M. (2010), "Do Perceptions Become Reality? the Moderating Role of Supply Chain Resiliency on Disruption Occurrence”, Journal of Business Logistics, Vol. 31 No. 2, pp. 1-20. 


\section{Appendix A}

Table 1A: SCRES Definitions

\begin{tabular}{|c|c|}
\hline Authors & SCRES Definitions \\
\hline Peck (2005, p. 211) & $\begin{array}{l}\text { Resilience is defined as "the ability of a system to return to its } \\
\text { original [or desired] state after being disturbed". The definition is } \\
\text { rooted in ecology (the study of the relationships between living } \\
\text { organisms and their environment) and was adopted because it sits } \\
\text { comfortably with the view of supply chains as interacting } \\
\text { networks. }\end{array}$ \\
\hline
\end{tabular}

Peck (2006, p. 132) The ability of the system to return to its original or desired state after being disturbed, i.e. its ability to absorb or mitigate the impact of the disturbance.

Sarathy (2006, p. 40) A resilient supply chain is one that can bounce back quickly from a disruption.

Williams et al. (2009, p. Resiliency is defined as the "ability to react to unexpected disruption and restore normal supply network operations".

Stewart et al. (2009, p. A process linking a set of adaptive capabilities to a positive 349)

Pereira (2009, p. 374) trajectory of functioning and adaptation after a disturbance A resilient supply chain with the ability to maintain, resume, and restore its original (or desired) state after being disrupted should also be considered. (...) resilience should mean the ability to change smoothly and rapidly, by either creating redundancy or increasing flexibility.

Colicchia et al. (2010, p. Supply chain resilience is defined as the 'ability of a system to 681) return to its original (or desired) state or move to a new, more desirable state after being disturbed'.

Melnyk et al. (2010, p. Resilience ensures that the supply chain can recover quickly and 34) cost-effectively from disruptions caused by natural disasters (such as earthquakes), social factors (employee strikes), medical emergencies (epidemics such as $\mathrm{H} 1 \mathrm{~N} 1 \mathrm{flu}$ ), economic setbacks (the bankruptcy of a critical link in the chain) or technological failures (a software crisis). 


\begin{tabular}{|c|c|}
\hline Authors & SCRES Definitions \\
\hline $\begin{array}{l}\text { Higgins et al. (2010, p. } \\
\text { 964) }\end{array}$ & $\begin{array}{l}\text { Resilience is the capacity of a system to recover from disturbar } \\
\text { and maintain its structure, function and controls. }\end{array}$ \\
\hline $\begin{array}{l}\text { Yang and Yang (2010, p. } \\
1903)\end{array}$ & $\begin{array}{l}\text { ".. an organisation's capability to recover to the original } \\
\text { operating status before a disruption." }\end{array}$ \\
\hline $\begin{array}{l}\text { Kumar et al. (2010, p. } \\
3721)\end{array}$ & $\begin{array}{l}\text { "... resilient supply chain networks need to be built having the } \\
\text { ability to maintain, resume and restore operations after any } \\
\text { disruption." }\end{array}$ \\
\hline Klibi et al. $(2010$, p. 287$)$ & $\begin{array}{l}\text { "... resilience is the capability of a SCN to avoid disruptions or } \\
\text { quickly recover from failures." }\end{array}$ \\
\hline $\begin{array}{l}\text { Zsidisin and Wagner } \\
(2010, \text { p. } 3)\end{array}$ & $\begin{array}{l}\text { Supply chain resiliency consists of the ability to return to normal } \\
\text { performance levels following a supply chain disruption. }\end{array}$ \\
\hline $\begin{array}{l}\text { Kumar and Sosnoski, } \\
(2011, \text { p. 5432) }\end{array}$ & Resilient companies have the ability to withstand the unexpected. \\
\hline $\begin{array}{l}\text { Carvalho et al. (2011, p. } \\
\text { 154) }\end{array}$ & $\begin{array}{l}\text { Resilience refers to the ability of the supply chain to cope with } \\
\text { unexpected disturbances. }\end{array}$ \\
\hline Ishfaq (2012, p. 216) & $\begin{array}{l}\text { A resilient supply chain has the ability to maintain continuity in } \\
\text { operations under disruptions. }\end{array}$ \\
\hline $\begin{array}{l}\text { Spiegler et al. (2012, } \mathrm{p} \\
6182)\end{array}$ & $\begin{array}{l}\text { "the adaptive capability of the supply chain to prepare for } \\
\text { unexpected events, respond to disruptions, and recover from them } \\
\text { by maintaining continuity of operations at desired levels of } \\
\text { connectedness and control over structure and function", }\end{array}$ \\
\hline
\end{tabular}

Cabral et al. (2012, p. Resilience refers to the ability of the SC to cope with unexpected 4831) disturbances, and is concerned with the system's ability to return to its original state or to a new, more desirable, one following a disruptive shock.

Carvalho et al. (2012, p. Resilience is referred to as the ability of supply chains to cope 49) with unexpected disturbances.

Pettit et al. (2013, p. 46) “... resilience - the ability to survive, adapt, and grow in the face of turbulent change."

Schmitt and Singh (2012, “... resilience refers to the ability of a system or component to p. 23) bounce back from a setback (...). Resilience ... focuses on the ability of the firm to sustain operation and recovery quickly in the face of a disruption."

Johnson et al. (2013, p. “... resilience is considered to develop over time, enabling an 325) organisation, or network, to survive and thrive in the face of adversity and, to further strengthen its capability to make future adjustments."

Sawik (2013, p. 260) Resiliency refers to a firm's capacity to survive, adapt, and grow in the face of change and uncertainty.

Wu et al. (2013, p. 676) “... the ability to respond and recover from a stockout disruption." 


\begin{tabular}{ll}
\hline \multicolumn{1}{c}{ Authors } & \multicolumn{1}{c}{ SCRES Definitions } \\
\hline $\begin{array}{l}\text { Hearnshaw and Wilson } \\
(2013, \text { p. 458) }\end{array}$ & $\begin{array}{l}\text { For supply chain systems, resilience is critical as the success of } \\
\text { firms is often determined by the ability of the system as a whole } \\
\text { to continue to provide flows despite disturbances. }\end{array}$ \\
Wieland (2013, p. 655) & $\begin{array}{l}\text { A supply chain can thus be resilient if its original stable situation } \\
\text { is sustained or if a new stable situation is achieved as long as the } \\
\text { supply chain is able to "bounce back from a disruption". A supply } \\
\text { chain is resilient if it uses resources that enable it to cope with } \\
\text { change. }\end{array}$
\end{tabular}

Azevedo et al. (2013, p. “... resilience is referred to as the SC ability to cope with 134) unexpected disturbances."

Golgeci and Ponomarov "... supply chains that have an adaptive capability to prepare for (2013, p. 604) unexpected events, respond to disruptions, and recover from them by maintaining continuity of operations."

Voss and Williams (2013, Resilience is the "ability to react to unexpected disruptions and p. 324) restore normal supply network operations".

Pereira et al. (2014, p. Supply chain resilience is defined here as the capability of supply 627) chains to respond quickly to unexpected events so as to restore operations to the previous performance level or even to a new and better one.

Brandon-Jones et al. Supply chain resilience is defined as the ability of a system to (2014, p. 58)

Mandal (2014, p. 431)

Scholten et al. (2014, p. "the adaptive capability of the supply chain to prepare for 212) return to its original state, within an acceptable period of time, after being disturbed.

"... supply chain resilience is the ability of a supply chain to sustain operations profitably when faced with disruptive events." unexpected events, respond to disruption and recover from them by maintaining continuity of operations at the desired level of connectedness and control over structures and function"

Kristianto et al. (2014, p. Resilience is the ability of a system to return to its original state 39) or move to a new, more desirable state after being disturbed.

Gong et al. (2014, p. 104) A resilient supply chain is a system that has the ability to recover quickly from disruptions and ensure customers are minimally affected.

Urciuoli (2015, p. 14) “... resilience of supply chains, that is, the capability of supply chains to bounce back to stable conditions after a disruption."

Heckmann et al. (2015, p. Supply chain resilience is defined as a supply chain's ability to 125-6) return to its original or move to a new, more desirable state after being disturbed.

Rajesh and Ravi (2015, p. “... resilience that stands for the adaptive capability to respond to 343) disruptions and recovering from it needs to be considered in supplier selection." 


\begin{tabular}{|c|c|}
\hline Authors & SCRES Definitions \\
\hline $\begin{array}{l}\text { Sprecher et al. (2015, p. } \\
6741)\end{array}$ & $\begin{array}{l}\text { Resilience can be defined as the capacity of a system to tolerate } \\
\text { disruptions while retaining its structure and function. }\end{array}$ \\
\hline $\begin{array}{l}\text { Tukamuhabwa et al. } \\
(2015, \text { p. } 8)\end{array}$ & $\begin{array}{l}\text { The adaptive capability of a supply chain to prepare for and/or } \\
\text { respond to disruptions, to make a timely and cost-effective } \\
\text { recovery, and therefore progress to a post-disruption state of } \\
\text { operations - ideally, a better state than prior to the disruption. }\end{array}$ \\
\hline Kim et al. $(2015$, p. 50) & $\begin{array}{l}\text { "... define supply network resilience as a network-level attribute } \\
\text { to withstand disruptions that may be triggered at the node or arc } \\
\text { level. Consequently, supply network resilience is an emergent } \\
\text { structural property of a supply network." }\end{array}$ \\
\hline $\begin{array}{l}\text { Gölgeci and Ponomarov } \\
(2015 \text {, p. 269) }\end{array}$ & $\begin{array}{l}\text { "the adaptive capability of the supply chain to prepare for } \\
\text { unexpected events, respond to disruptions, and recover from them } \\
\text { by maintaining continuity of operations at the desired level of } \\
\text { connectedness and control over structure and function" }\end{array}$ \\
\hline Fiksel et al. (2015, p. 82) & $\begin{array}{l}\text { We define resilience as "the capacity of an enterprise to survive, } \\
\text { adapt and grow in the face of turbulent change." }\end{array}$ \\
\hline $\begin{array}{l}\text { Scholten and Schilder } \\
(2015, \text { p. 472) }\end{array}$ & $\begin{array}{l}\text { Resilience enables a supply chain to be prepared for events and } \\
\text { reduce the impact of a disruption, and strengthens the ability to } \\
\text { recover quickly from them by maintaining continuity of } \\
\text { operations at the desired level of connectedness and control over } \\
\text { structure and function. }\end{array}$ \\
\hline
\end{tabular}




\section{Appendix B}

Table 2B: Elements of SCRES based on SLR

\begin{tabular}{|c|c|c|}
\hline Elements & $\begin{array}{l}\text { No. of } \\
\text { Papers }\end{array}$ & Authors \\
\hline $\begin{array}{l}\text { Supply Chain } \\
\text { Design (SC Configuration) }\end{array}$ & 38 & $\begin{array}{l}\text { Christopher and Peck (2004), Blackhurst et al. (2005), Craighead } \text { et } \\
\text { al. (2007), Manuj and Mentzer (2008), Ratick et al. (2008), } \\
\text { Knemeyer et al. (2009), Stecke and Kumar (2009), Higgins et al. } \\
\text { (2010), Klibi et al. (2010), Blackhurst et al. (2011), Carvalho et al. } \\
\text { (2011), Christopher et al. (2011), Vugrin et al. (2011), Khan et al. } \\
\text { (2012), Klibi and Martel (2012), Mandal (2012), Ponis and Koronis } \\
\text { (2012), Schmitt and Singh (2012), Bhattacharya et al. (2013), } \\
\text { Harrison } \text { et al. (2013), Hearnshaw and Wilson (2013), Abe (2014), } \\
\text { Chopra and Sodhi (2014), Day (2014), Gong et al. (2014), Kristianto } \\
\text { et al. (2014), Pereira et al. (2014), Sáenz and Revilla (2014), Scholten } \\
\text { et al. (2014), Soni et al. (2014), Melnyk et al. (2014), Boyes et al. } \\
\text { (2015), Davis (2015), Kim et al. (2015), Mari et al. (2015), Matsuo } \\
\text { (2015), Seville et al. (2015), Thomas et al. (2015) }\end{array}$ \\
\hline
\end{tabular}

Flexibility

Redundancy
37

Rice and Caniato (2003), Blackhurst et al. (2005), Sheffi and Rice (2005), Datta et al. (2007), Manuj and Mentzer (2008), Tang and Tomlin (2008), Ponomarov and Holcomb (2009), Stecke and Kumar (2009), Blos et al. (2010), Pettit et al. (2010), Yang and Yang (2010), Zsidisin and Wagner (2010), Blackhurst et al. (2011), Carvalho et al. (2011), Jüttner and Maklan (2011), Cabral et al. (2012), Carvalho et al. (2012), Ishfaq (2012), Azevedo et al. (2013), Harrison et al. (2013), Johnson et al. (2013), Pettit et al. (2013), Aigbogun et al. (2014), Azadeh et al. (2014), Carvalho et al. (2014), Kristianto et al. (2014), Scholten et al. (2014), Melnyk et al. (2014), Urciuoli et al. (2014), Ambulkar et al. (2015), Fiksel et al. (2015), Mari et al. (2015), Rajesh and Ravi (2015), Scholten and Schilder (2015), Sprecher et al. (2015), Todo et al. (2015), Yang and Xu (2015)

Rice and Caniato (2003), Peck (2005), Sheffi and Rice (2005), Craighead et al. (2007), Datta et al. (2007), Ratick et al. (2008), Ponomarov and Holcomb (2009), Stecke and Kumar (2009), Melnyk et al. (2010), Pettit et al. (2010), Yang and Yang (2010), Zsidisin and Wagner (2010), Blackhurst et al. (2011), Carvalho et al. (2011), Carvalho et al. (2012), Klibi and Martel (2012), Ponis and Koronis (2012), Pereira et al. (2014), Schmitt and Singh (2012), Pettit et al. 


\begin{tabular}{|c|c|c|}
\hline Elements & $\begin{array}{l}\text { No. of } \\
\text { Papers }\end{array}$ & Authors \\
\hline & & $\begin{array}{l}\text { (2013), Wu et al. (2013), Aigbogun et al. (2014), Azadeh et al. } \\
\text { (2014), Carvalho et al. (2014), Ivanov et al. (2014), Melnyk et al. } \\
\text { (2014), Urciuoli et al. (2014), Ambulkar et al. (2015), Fiksel et al. } \\
\text { (2015), Hohenstein et al. (2015) }\end{array}$ \\
\hline
\end{tabular}

Visibility (Monitoring, KPI, 29 Measuring)

Collaboration/Collaborative Planning

Agility/Responsiveness

Anticipation/Awareness/

Sensing

IT Capability (Information Sharing)

Robustness
Christopher and Peck (2004), Blackhurst et al. (2005), Stecke and Kumar (2009), Blos et al. (2010), Melnyk et al. (2010), Pettit et al. (2010), Blackhurst et al. (2011), Carvalho et al. (2011), Jüttner and Maklan (2011), Ponis and Koronis (2012), Azevedo et al. (2013), Glendon (2013), Johnson et al. (2013), Pettit et al. (2013), Wieland and Wallenburg (2013), Aigbogun et al. (2014), Azadeh et al. (2014), Brandon-Jones et al. (2014), Carvalho et al. (2014), Pereira et al. (2014), Sáenz and Revilla (2014), Soni et al. (2014), Ambulkar et al. (2015), Davis (2015), Durach et al. (2015), Fiksel et al. (2015), Hohenstein et al. (2015), Rajesh and Ravi (2015), Scholten and Schilder (2015)

Christopher and Peck (2004), Bakshi and Kleindorfer (2009), Pettit et al. (2010), Jüttner and Maklan (2011), Christopher et al. (2011), VanVactor (2011), Mandal (2012), Ponis and Koronis (2012), Glendon (2013), Johnson et al. (2013), Leat and Revoredo-Giha (2013), Pettit et al. (2013), Wieland and Wallenburg (2013), Aigbogun et al. (2014), Carvalho et al. (2014), Pereira et al. (2014), Scholten et al. (2014), Soni et al. (2014), Fiksel et al. (2015), Hohenstein et al. (2015), Rajesh and Ravi (2015), Scholten and Schilder (2015), Todo et al. (2015)

Christopher and Peck (2004), Tang and Tomlin (2008), Ponomarov and Holcomb (2009), Klibi et al. (2010), Kumar et al. (2010), Carvalho et al. (2011), Ismail et al. (2011), Christopher et al. (2011), Cabral et al. (2012), Mandal (2012), Ponis and Koronis (2012), Wieland (2013), Wieland and Wallenburg (2013), Carvalho et al. (2014), Ivanov et al. (2014), Pereira et al. (2014), Scholten et al. (2014), Soni et al. (2014), Hohenstein et al. (2015), Mari et al. (2015), Rajesh and Ravi (2015)

Christopher and Peck (2004), Peck (2005), Craighead et al. (2007), Datta et al. (2007), Pettit et al. (2010), Pettit et al. (2013), Wieland and Wallenburg (2013), Sáenz and Revilla (2014), Melnyk et al. (2014), Ambulkar et al. (2015), Fiksel et al. (2015), Rajesh and Ravi (2015), Seville et al. (2015), Stevenson and Busby (2015)

Pereira (2009), Ponomarov and Holcomb (2009), Melnyk et al. (2010), Day (2014), Pereira et al. (2014), Scholten et al. (2014), Soni et al. (2014), Melnyk et al. (2014), Ambulkar et al. (2015), Boyes (2015), Davis (2015), Rajesh and Ravi (2015), Stevenson and Busby (2015), Urciuoli (2015)

Blackhurst et al. (2005), Tang (2006), Stecke and Kumar (2009), Klibi et al. (2010), Klibi and Martel (2012), Spiegler et al. (2012), Berle et al. (2013), Wieland (2013), Wieland and Wallenburg (2013), Durach et al. (2015), Mari et al. (2015), Sprecher et al. (2015) 


\begin{tabular}{|c|c|c|}
\hline Elements & $\begin{array}{l}\text { No. of } \\
\text { Papers }\end{array}$ & Authors \\
\hline $\begin{array}{l}\text { SCRM Culture/Department } \\
\text { Managing Risk }\end{array}$ & 12 & $\begin{array}{l}\text { Rice and Caniato (2003), Christopher and Peck (2004), Sheffi and } \\
\text { Rice (2005), Williams et al. (2009), Dowty and Wallace (2010), } \\
\text { Christopher et al. (2011), Mandal (2012), Soni et al. (2014), } \\
\text { Ambulkar et al. (2015), Durach et al. (2015), Seville et al. (2015), } \\
\text { Stevenson and Busby (2015) }\end{array}$ \\
\hline Security & 12 & $\begin{array}{l}\text { Rice and Caniato (2003), Sarathy (2006), Manuj and Mentzer (2008), } \\
\text { Bakshi and Kleindorfer (2009), Williams et al. (2009), Pettit et al. } \\
\text { (2010), Blackhurst et al. (2011), Pettit et al. (2013), Voss and } \\
\text { Williams (2013), Melnyk et al. (2014), Fiksel et al. (2015), Stevenson } \\
\text { and Busby (2015) }\end{array}$ \\
\hline $\begin{array}{l}\text { Knowledge } \\
\text { Management/HRM }\end{array}$ & 11 & $\begin{array}{l}\text { Rice and Caniato (2003), Ponomarov and Holcomb (2009), Stecke } \\
\text { and Kumar (2009), Blackhurst et al. (2011), Jüttner and Maklan } \\
\text { (2011), Pereira et al. (2014), Scholten et al. (2014), Ambulkar et al. } \\
\text { (2015), Hohenstein et al. (2015), Seville et al. (2015), Stevenson and } \\
\text { Busby (2015) }\end{array}$ \\
\hline $\begin{array}{l}\text { SC Continuity/Contingency } \\
\text { plans }\end{array}$ & 11 & $\begin{array}{l}\text { Blackhurst et al. (2005), Craighead et al. (2007), Ponomarov and } \\
\text { Holcomb (2009), Blos et al. (2010), Colicchia et al. (2010), Melnyk } \\
\text { et al. (2010), Levesque (2012), Gong et al. (2014), Hohenstein et al. } \\
\text { (2015), Rajesh and Ravi (2015), Seville et al. (2015) }\end{array}$ \\
\hline Velocity & 10 & $\begin{array}{l}\text { Christopher and Peck (2004), Jüttner and Maklan (2011), Ponis and } \\
\text { Koronis (2012), Johnson et al. (2013), Azadeh et al. (2014), Carvalho } \\
\text { et al. (2014), Pereira et al. (2014), Rajesh and Ravi (2015), Scholten } \\
\text { and Schilder (2015), Sprecher et al. (2015) }\end{array}$ \\
\hline Coordination & 7 & $\begin{array}{l}\text { Craighead et al. (2007), Datta et al. (2007), Knemeyer et al. (2009), } \\
\text { Stecke and Kumar (2009), Pereira et al. (2014), Seville et al. (2015), } \\
\text { Todo } \text { et al. (2015) }\end{array}$ \\
\hline Integration/Connectivity & 7 & $\begin{array}{l}\text { Ponomarov and Holcomb (2009), Melnyk et al. (2010), Carvalho et } \\
\text { al. (2011), Brandon-Jones et al. (2014), Pereira et al. (2014), Davis } \\
\text { (2015), Seville } \text { et al. } \text { (2015) }\end{array}$ \\
\hline Adaptability & 6 & $\begin{array}{l}\text { Pettit et al. (2010), Pettit et al. (2013), Aigbogun et al. (2014), Soni et } \\
\text { al. (2014), Fiksel et al. (2015), Seville et al. (2015) }\end{array}$ \\
\hline Market Position & 6 & $\begin{array}{l}\text { Sheffi and Rice (2005), Pettit et al. (2010), Pettit et al. (2013), Wu et } \\
\text { al. (2013), Melnyk et al. (2014), Fiksel et al. (2015) }\end{array}$ \\
\hline $\begin{array}{l}\text { Risk Control/Transfer or } \\
\text { Risk/Revenue Sharing }\end{array}$ & 6 & $\begin{array}{l}\text { Manuj and Mentzer (2008), Ponomarov and Holcomb (2009), } \\
\text { Carvalho et al. (2011), Kumar and Sosnoski (2011), Sawik (2013), } \\
\text { Soni et al. (2014) }\end{array}$ \\
\hline Alignment & 5 & $\begin{array}{l}\text { Ismail et al. (2011), Khan et al. (2012), Boone et al. (2013), Pereira et } \\
\text { al. (2014), Seville et al. (2015) }\end{array}$ \\
\hline Financial Strength & 5 & $\begin{array}{l}\text { Pettit et al. (2010), Pettit et al. (2013), Day (2014), Melnyk et al. } \\
\text { (2014), Fiksel et al. (2015) }\end{array}$ \\
\hline $\begin{array}{l}\text { Public-Private Partnership } \\
\text { (PPP) }\end{array}$ & 5 & $\begin{array}{l}\text { Stewart et al. (2009), Voss and Williams (2013), Stevenson and } \\
\text { Busby (2015), Urciuoli (2015), Yang and Xu (2015) }\end{array}$ \\
\hline Efficiency & 4 & $\begin{array}{l}\text { Ponomarov and Holcomb (2009), Pettit et al. (2010), Pettit et al. } \\
\text { (2013), Fiksel et al. (2015) }\end{array}$ \\
\hline Trust & 4 & $\begin{array}{l}\text { Day (2014), Pereira et al. (2014), Soni et al. (2014), Seville et al. } \\
\text { (2015) }\end{array}$ \\
\hline $\begin{array}{l}\text { Building Social Capital and } \\
\text { Relational Competences }\end{array}$ & 3 & $\begin{array}{l}\text { Johnson et al. (2013), Wieland and Wallenburg (2013), Seville et al. } \\
\text { (2015) }\end{array}$ \\
\hline Increasing Innovativeness & 3 & $\begin{array}{l}\text { Golgeci and Ponomarov (2013), Melnyk et al. (2014), Gölgeci and } \\
\text { Ponomarov (2015) }\end{array}$ \\
\hline
\end{tabular}




\begin{tabular}{lll}
\hline \multicolumn{1}{c}{ Elements } & $\begin{array}{c}\text { No. of } \\
\text { Papers }\end{array}$ & Authors \\
\hline Sustainability & 2 & Soni et al. (2014), Rajesh and Ravi (2015) \\
\hline
\end{tabular}

